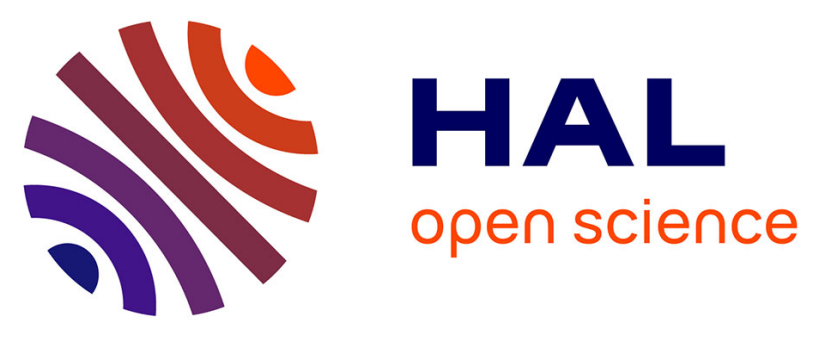

\title{
Two-Step Thermoinduced Metal-to-Metal Electron Transfer and ON/OFF Photoswitching in a Molecular [Fe 2 Co 2 ] Square Complex
}

Sujit Kamilya, Subrata Ghosh, Yanling Li, Pierre Dechambenoit, Mathieu Rouzières, Rodrigue Lescouëzec, Sakshi Mehta, Abhishake Mondal

\section{To cite this version:}

Sujit Kamilya, Subrata Ghosh, Yanling Li, Pierre Dechambenoit, Mathieu Rouzières, et al.. Two-Step Thermoinduced Metal-to-Metal Electron Transfer and ON/OFF Photoswitching in a Molecular [Fe 2 Co 2 ] Square Complex. Inorganic Chemistry, 2020, 59 (17), pp.11879-11888. 10.1021/acs.inorgchem.0c02053 . hal-03082269

\section{HAL Id: hal-03082269 https://hal.science/hal-03082269}

Submitted on 18 Dec 2020

HAL is a multi-disciplinary open access archive for the deposit and dissemination of scientific research documents, whether they are published or not. The documents may come from teaching and research institutions in France or abroad, or from public or private research centers.
L'archive ouverte pluridisciplinaire HAL, est destinée au dépôt et à la diffusion de documents scientifiques de niveau recherche, publiés ou non, émanant des établissements d'enseignement et de recherche français ou étrangers, des laboratoires publics ou privés. 


\title{
Two-Step Thermoinduced Metal-to-Metal Electron Transfer and ON/ OFF Photoswitching in a Molecular $\left[\mathrm{Fe}_{2} \mathrm{Co}_{2}\right]$ Square Complex
}

\author{
Sujit Kamilya, Subrata Ghosh, Yanling Li, Pierre Dechambenoit, Mathieu Rouzières, \\ Rodrigue Lescouëzec, Sakshi Mehta, and Abhishake Mondal*
}

ABSTRACT: A cyanide-bridged $\left[\mathrm{Fe}_{2} \mathrm{Co}_{2}\right]$ molecular square complex, $\left\{\left[\mathrm{Fe}(\mathrm{Tp})(\mathrm{CN})_{3}\right]_{2}\left[\mathrm{Co}(\mathbf{L})_{2}\right]_{2}\right\}\left(\mathrm{BF}_{4}\right)_{2} \cdot 2 \mathrm{CH}_{3} \mathrm{CN} \cdot 6 \mathrm{H}_{2} \mathrm{O}[\mathbf{1}$; $\mathrm{Tp}=$ hydrotris(pyrazol-1-yl)borate and $\mathbf{L}=$ bis(1-ethyl- $1 H$ imidazol-2-yl)ketone], has been synthesized and characterized fully by single-crystal X-ray diffraction, (photo)magnetic measurements, optical reflectivity, and other physical measurements. 1 exhibits a two-step metal-to-metal electron-transfer (MMET)induced spin transition accompanied by thermal hysteresis $\left(T_{1 / 2} \uparrow\right.$ $=332$ and $407 \mathrm{~K}$ and $T_{1 / 2} \downarrow=320$ and $405 \mathrm{~K}$, respectively), converting the low-temperature diamagnetic $\left\{\mathrm{Fe}^{\mathrm{II}}{ }_{\mathrm{LS}}-\mathrm{CN}-\mathrm{Co}^{\mathrm{III}}{ }_{\mathrm{LS}}\right\}$ ground state into the high-temperature paramagnetic $\left\{\mathrm{Fe}^{\mathrm{III}}{ }_{\mathrm{LS}}{ }^{-}\right.$
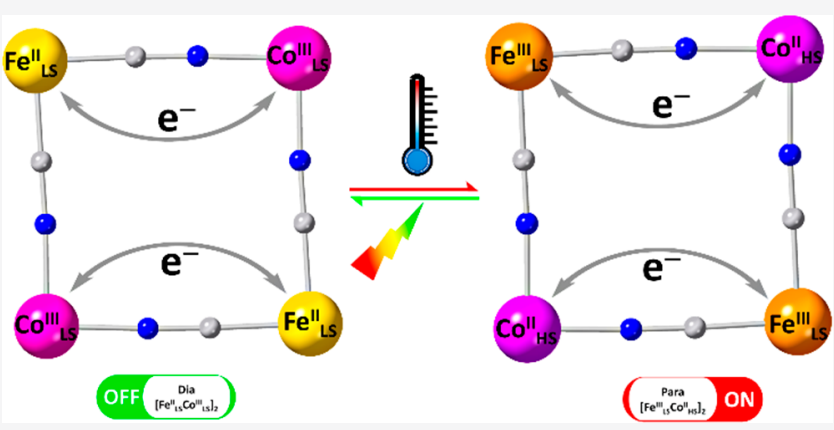
$\left.\mathrm{CN}-\mathrm{Co}^{\mathrm{II}}{ }_{\mathrm{HS}}\right\}$ state. Additionally, 1 displays reversible photoinduced MMET under light irradiation (ON mode using $808 \mathrm{~nm}$ laser light and OFF mode using $532 \mathrm{~nm}$ laser light), as confirmed by optical reflectivity and (photo)magnetic measurements. The photoinduced paramagnetic metastable state relaxes back to the diamagnetic ground state at $91 \mathrm{~K}\left(T_{\text {LIESST }}=91 \mathrm{~K}\right)$. Astonishingly, 1 also exhibits a $27 \mathrm{~K}$ wide light-induced thermal hysteresis below $100 \mathrm{~K}$. The overall results show that $\mathbf{1}$ is a multistimuli-responsive bistable material that exhibits reversible switching between the diamagnetic state, $\left\{\mathrm{Fe}_{\mathrm{LS}}^{\mathrm{II}}-\mathrm{CN}-\mathrm{Co}^{\mathrm{III}}{ }_{\mathrm{LS}}\right\}$, and the paramagnetic state, $\left\{\mathrm{Fe}^{\mathrm{III}}{ }_{\mathrm{LS}}-\mathrm{CN}-\mathrm{Co}^{\mathrm{II}}{ }_{\mathrm{HS}}\right\}$, under the application of temperature and light.

\section{INTRODUCTION}

Magnetic materials and switches have attracted great interest in the field of material sciences from the last 2 decades because of huge potential applications in future electronic devices. ${ }^{1}$ Bistable molecules that exhibit ON/OFF switching of their magnetization with the application of various external perturbations, e.g., temperature, ${ }^{2}$ pressure ${ }^{3}$ light, ${ }^{4}$ electric field, ${ }^{5}$ etc., are the best candidates for information storage, ${ }^{6}$ switches, ${ }^{7}$ and sensor devices ${ }^{8}$ at a molecular level. So far, materials based on cyanide-bridged Prussian Blue (PB) and its analogues (PBAs) have shown their potential and also become an eminent example in this growing field with its exciting reversible switching of (photo)physical properties. It has been started with the revolutionary example of metal-to-metal electron transfer (MMET) occurring between iron and cobalt centers via a cyanide bridge in a $[\mathrm{FeCo}] \mathrm{PBA}, \mathrm{K}_{0.2} \mathrm{Co}_{1.4}[\mathrm{Fe}-$ $\left.(\mathrm{CN})_{6}\right] \cdot 6.9 \mathrm{H}_{2} \mathrm{O}$, where the low-temperature $\left\{\mathrm{Fe}^{\mathrm{II}}{ }_{\mathrm{LS}}(S=0)-\right.$ $\left.\mathrm{CN}-\mathrm{Co}_{\mathrm{LS}}^{\mathrm{III}}(\mathrm{S}=0)\right\}$ diamagnetic ground state changes into the metastable $\left\{\mathrm{Fe}_{\mathrm{LS}}^{\mathrm{III}}(S=1 / 2)-\mathrm{CN}-\mathrm{Co}^{\mathrm{II}}{ }_{\mathrm{HS}}(S=3 / 2)\right\}$ paramagnetic state via light irradiation at $5 \mathrm{~K}^{9}$. In 2004, Dunbar et al. synthesized the first-ever thermally induced MMET in a discrete cyanide-bridged $\left[\mathrm{Co}_{3} \mathrm{Fe}_{2}\right]$ complex, ${ }^{10}$ and later in 2011, the (photo)magnetic effect of this complex was studied by Clérac and Dunbar et al. ${ }^{11}$ After that, various molecular model complexes of [FeCo] PBAs; e.g., molecular cubes, ${ }^{12,13}$ squares, ${ }^{14-21}$ and dinuclear units ${ }^{22,23}$ have been reported by different research groups, including us, which exhibit thermoand/or photoinduced MMET. ${ }^{24,25}$ Additionally, a few [FeCo] systems have also been investigated where the photoinduced metastable state exhibits a slow relaxation of magnetization, i.e., single molecule magnets, ${ }^{26,27}$ while some $1 \mathrm{D}$ [FeCo] chains exhibit interesting single chain magnet properties in the photoinduced state. ${ }^{28-31}$ All of these stimuli-responsive materials open a new horizon in the field of electronic device technology with their huge potential. ${ }^{32}$ The most challenging task down the lane is to synthesize a multiresponsive material that will exhibit bistability at ambient conditions. To the best of our knowledge, until now there is no such example of the $\left\{\mathrm{Fe}_{2} \mathrm{Co}_{2}\right\}$ molecular square complex that exhibits thermoinduced two-step MMET, accompanied by thermal hysteresis and ON/OFF photoswitching and the light-induced thermal hysteresis effect (LITH). 
In this aspect, herein we present our recent works with a significant focus on the development and a better understanding of the role of the redox potential along with intra- and intermolecular interactions associated with the stimuliresponsive reversible electron-transfer properties of a $\left\{\mathrm{Fe}_{2} \mathrm{Co}_{2}\right\}$ molecular square complex. Applying building block as a ligand strategy, we have used here the cyanide building block (TBA) $\left[\mathrm{Fe}^{\mathrm{III}}(\mathrm{Tp})(\mathrm{CN})_{3}\right] \cdot \mathrm{H}_{2} \mathrm{O}[\mathrm{Tp}=$ hydrotris (pyrazol1 -yl)borate] to prepare the molecular model complex of [FeCo] PBAs, i.e., the $\left\{\mathrm{Fe}_{2} \mathrm{Co}_{2}\right\}$ square complex $\{[\mathrm{Fe}(\mathrm{Tp})$ $\left.\left.(\mathrm{CN})_{3}\right]_{2}\left[\mathrm{Co}(\mathbf{L})_{2}\right]_{2}\right\}\left(\mathrm{BF}_{4}\right)_{2} \cdot 2 \mathrm{CH}_{3} \mathrm{CN} \cdot 6 \mathrm{H}_{2} \mathrm{O} \quad[\mathbf{1} ; \mathbf{L}=\operatorname{bis}(1-$ ethyl-1H-imidazol-2-yl)ketone] and explored the structural, (photo)magnetic, and optical properties during the MMET process.

\section{RESULTS AND DISCUSSION}

Synthesis. The reaction of (TBA) $\left[\mathrm{Fe}^{\mathrm{III}}(\mathrm{Tp})(\mathrm{CN})_{3}\right] \cdot \mathrm{H}_{2} \mathrm{O}$ with a solution of $\mathrm{Co}\left(\mathrm{BF}_{4}\right)_{2} \cdot 6 \mathrm{H}_{2} \mathrm{O}$ and the $\mathrm{L}$ ligand in a mixture of acetonitrile/water (9:1) afforded a green reaction mixture. Slow evaporation of the reaction mixture gave analytically pure green crystals of $\mathbf{1}$ in good yield. The purity of the complex has been studied by elemental analyses and powder X-ray diffraction (PXRD) measurements (Figure S1). The thermal stability of $\mathbf{1}$ was investigated by thermogravimetric analysis (TGA) in the temperature range of 300-600 K with a scan rate of $5 \mathrm{~K} \mathrm{~min}^{-1}$ under a nitrogen atmosphere (Figure S2). 1 first undergoes a weight loss between 300 and $353 \mathrm{~K}$ (ca. 2.7\%), corresponding to a partial release of interstitial solvent molecules. After that, 1 shows thermal stability up to $450 \mathrm{~K}$. The partial solvent loss is probably the reason for the slight deviation in the experimental PXRD data.

Structure Analysis. Single-crystal X-ray structure analysis was performed on suitable single crystal of 1 at $120 \mathrm{~K}$ (Figure $1)$. The complex crystallizes in the triclinic $P \overline{1}$ space group $(Z$ = 1; Table S1) and consists of a $\left\{\mathrm{Fe}_{2} \mathrm{Co}_{2}\right\}$ square structural motif where the iron and cobalt centers occupy an alternate corner of the square and are bridged by cyanide ions. Each iron

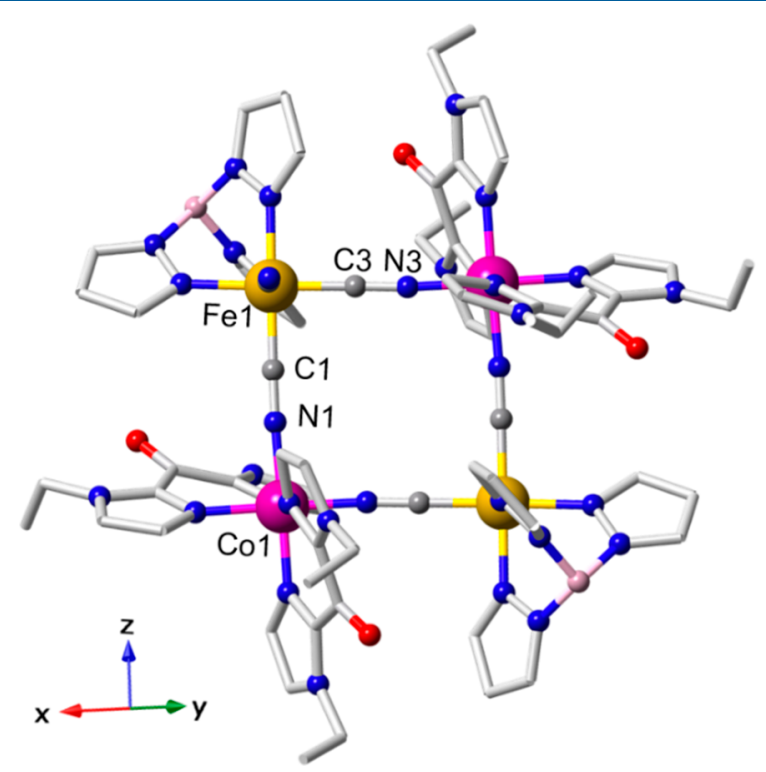

Figure 1. Perspective view of the cyanide-bridged $\left\{\mathrm{Fe}_{2} \mathrm{Co}_{2}\right\}$ square unit of $\mathbf{1}$. Solvent molecules, hydrogen atoms, and counteranions are omitted for clarity. Color code: Fe, yellow; Co, purple; C, gray; N, blue; O, red; B, light pink. center is in a distorted-octahedral geometry with a $\mathrm{FeC}_{3} \mathrm{~N}_{3}$ coordination environment that can best be described by using the continuous shape measures (CShM) program $^{33}$ (Table S2), where the iron center is coordinated to three nitrogendonor atoms of the Tp ligand and three carbon-donor atoms from two bridging and one terminal cyanide ligands.

The coordination geometry around each cobalt center is best described as a slightly distorted octahedron with surrounding $\mathrm{CoN}_{6}$ (Table S2), in which the cobalt center is coordinated to four nitrogen-donor atoms of two L ligands and two nitrogen-donor atoms of two bridging cyanide ligands. The overall structure of 1 consists of a dicationic $\{[\mathrm{Fe}(\mathrm{Tp})$ $\left.\left.(\mathrm{CN})_{3}\right]_{2}\left[\mathrm{Co}(\mathrm{L})_{2}\right]_{2}\right\}^{2+}$ square unit, two $\mathrm{BF}_{4}^{-}$counteranions, and interstitial water and acetonitrile solvent molecules (Figure S3). Estimations of their numbers are 6 and 2, respectively, but their exact number must be taken with care because some of them had to be squeezed (see the Supporting Information). ${ }^{34}$ In 1 , the $\mathrm{Fe}-\mathrm{C}$ and $\mathrm{Fe}-\mathrm{N}$ bond distances are in the ranges of $1.860(3)-1.905(4)$ and $1.994(3)-1.999(3) \AA$, respectively (Table S3), which are in agreement with a low-spin (LS) iron(II) state in a $\mathrm{FeC}_{3} \mathrm{~N}_{3}$ distorted octahedral geometry. ${ }^{12-20,24}$

The average Co-N bond distance is $1.912 \AA$, lying in the range expected for the LS cobalt(III) ion in a $\mathrm{CoN}_{6}$ distorted octahedral coordination environment, where typical $\mathrm{Co}-\mathrm{N}$ bond distances of LS cobalt(III) and high-spin (HS) cobalt(II) are $\sim 1.9$ and $\sim 2.1 \AA$, respectively. ${ }^{12-20,35-38}$ The Fe-CN-Co edges are almost identical with distances of 4.892(1) and 4.888(1) $\AA$, and angles at the corners are close to the orthogonality $\left[\mathrm{C} 1-\mathrm{Fe} 1-\mathrm{C} 3=88.71(14)^{\circ}\right.$ and $\mathrm{N} 1-\mathrm{Co} 1-\mathrm{N} 3$ $=91.73(12)^{\circ}$; Table S4]. The cyanide bridges are slightly more bent on the cobalt side $\left[\mathrm{Co} 1-\mathrm{N} 1-\mathrm{C} 1=178.0(3)^{\circ}\right.$ and $\mathrm{Co} 1-$ $\left.\mathrm{N} 3-\mathrm{C} 3=174.9(3)^{\circ}\right]$ than on the iron side, which remains close to linearity $\left[\mathrm{Fe} 1-\mathrm{C} 1-\mathrm{N} 1=178.3(3)^{\circ}\right.$ and $\mathrm{Fe} 1-\mathrm{C} 3-\mathrm{N} 3$ $\left.=179.3(3)^{\circ}\right]$. All of these geometric features indicate the presence of a $\left\{\mathrm{Fe}_{\mathrm{LS}}^{\mathrm{II}}-\mathrm{CN}-\mathrm{Co}{ }_{\mathrm{LS}}\right\}_{2}$ square moiety in $\mathbf{1}$ at 120 $\mathrm{K}$. The high-temperature single-crystal X-ray diffraction (SCXRD) data collection of $\mathbf{1}$ at $300 \mathrm{~K}$ or above has remained unsuccessful even after several attempts because the crystals lose crystallinity as a result of interstitial solvent loss. In $\mathbf{1}$, the nonbridging cyanide groups are involved in hydrogen-bonding interaction with the interstitial water molecules (Figure S4). Weak supramolecular interactions $(\mathrm{C}-\mathrm{H} \cdots \mathrm{N}$ and $\mathrm{C}-\mathrm{H} \cdots \mathrm{F})$ have been observed between the molecular square motif, acetonitrile solvent molecules, and $\mathrm{BF}_{4}^{-}$counteranions in $\mathbf{1}$ (Figure S4). In addition, various $\mathrm{C}-\mathrm{H} \cdots \mathrm{N}$ and $\mathrm{C}-\mathrm{H} \cdots \mathrm{C}$ interactions between the square motifs form a supramolecular chain in $\mathbf{1}$ (Figure S5). The $\left\{\mathrm{Fe}_{2} \mathrm{Co}_{2}\right\}$ square units in $\mathbf{1}$ are isolated quite well from each other, with the shortest intermolecular metal-metal distance of $8.759(1) \AA$ (Fe...Co).

Spectroscopic Studies. IR spectroscopy has been considered to be an important tool in characterizing the electronic states and bridging modes of cyanide-bridged metal complexes because the cyanide stretching frequencies $\nu_{\mathrm{CN}}$ are sensitive to the oxidation states as well as the spin states of the cyanide-bridged metal complexes. ${ }^{12-20,24,25,37,39-41}$ Also, $\nu_{\mathrm{BH}}$ and $\nu_{\mathrm{CO}}$ of the $\mathrm{Tp}$ and $\mathrm{L}$ ligands, respectively, are significantly sensitive to the electronic nature (both spin and oxidation states) of the coordinated metal ions. Therefore, IR measurements were carried out on the $\mathbf{L}$ ligand, building block (TBA) $\left[\mathrm{Fe}^{\mathrm{III}}(\mathrm{Tp})(\mathrm{CN})_{3}\right] \cdot \mathrm{H}_{2} \mathrm{O}$, L-coordinated cobalt complex $\left[\mathrm{Co}(\mathrm{L})_{3}\right]^{2+}$, and complex 1 at $300 \mathrm{~K}$ (Figures S6-S8). The IR spectrum of $(\mathrm{TBA})\left[\mathrm{Fe}^{\mathrm{III}}(\mathrm{Tp})(\mathrm{CN})_{3}\right] \cdot \mathrm{H}_{2} \mathrm{O}$ exhibits character- 
istic $\nu_{\mathrm{CN}}$ and $\nu_{\mathrm{BH}}$ bands at 2117 and $2510 \mathrm{~cm}^{-1}$, respectively (Figure S7). At $300 \mathrm{~K}$, the IR spectrum of 1 shows three $\nu_{\mathrm{CN}}$ bands at 2127,2112 , and $2065 \mathrm{~cm}^{-1}$ (Figure S8). The first two bands are attributed to the bridging $\nu_{\mathrm{CN}}$ band of the $\left\{\mathrm{Fe}_{\mathrm{LS}}^{\mathrm{II}}-\right.$ $\left.\mathrm{CN}-\mathrm{Co}^{\mathrm{III}}{ }_{\mathrm{LS}}\right\}$ unit, while the latter band can be ascribed to the $\nu_{\mathrm{CN}}$ band of terminal $\mathrm{Fe}^{\mathrm{II}}{ }_{\mathrm{LS}}-\mathrm{CN}$ of the $\left[\mathrm{Fe}^{\mathrm{II}}(\mathrm{Tp})(\mathrm{CN})_{3}\right]^{2-}$ unit. $^{12-20,22-25,37,39-41}$ The characteristic $\nu_{\mathrm{BH}}$ band was observed at $2468 \mathrm{~cm}^{-1}$, which is significantly lower than that found in the (TBA) $\left[\mathrm{Fe}^{\mathrm{III}}(\mathrm{Tp})(\mathrm{CN})_{3}\right] \cdot \mathrm{H}_{2} \mathrm{O} \quad\left(2510 \mathrm{~cm}^{-1}\right)$ building block and very similar to that reported for the $\left[\mathrm{Fe}^{\mathrm{II}}(\mathrm{Tp})(\mathrm{CN})_{3}\right]^{2-}$ unit, suggesting the presence of an iron(II) oxidation state. $^{12-20,22-25,37,39-41}$ The peak at $1663 \mathrm{~cm}^{-1}$ corresponds to the $\nu_{\mathrm{CO}}$ band of the coordinated $\mathbf{L}$ ligand, which is significantly shifted to higher energy in comparison to the free ligand $\left(1630 \mathrm{~cm}^{-1}\right)$ and $\mathrm{HS}\left[\mathrm{Co}(\mathrm{L})_{3}\right]^{2+}$ complex $\left(1641 \mathrm{~cm}^{-1}\right) .{ }^{12}$ Additionally, the presence of four characteristic peaks in the range of $1030-1115 \mathrm{~cm}^{-1}$ indicates the presence of $\mathrm{BF}_{4}^{-}$counteranions in $\mathbf{1}$. All of these results suggest the presence of the $\left\{\mathrm{Fe}^{\mathrm{II}}{ }_{\mathrm{LS}}-\mathrm{CN}-\mathrm{Co}^{\mathrm{III}}{ }_{\mathrm{LS}}\right\}$ square moiety in $\mathbf{1}$ at $300 \mathrm{~K}$.

Variable-temperature IR measurements were performed on 1 in the temperature range of $300-420 \mathrm{~K}$ in both heating and cooling modes with $10 \mathrm{~K}$ intervals (Figures S9-S12). Upon an increase in the temperature, the intensities of the three $\nu_{\mathrm{CN}}$ bands of 1 were decreased with the appearance of three new bands at 2169, 2163, and $2120 \mathrm{~cm}^{-1}$ (Figure S10). The former two bands lie in the range expected for the bridging $\nu_{\mathrm{CN}}$ band of the $\left\{\mathrm{Fe}^{\mathrm{III}}{ }_{\mathrm{LS}}-\mathrm{CN}-\mathrm{Co}_{\mathrm{HS}}^{\mathrm{II}}\right\}$ unit. ${ }^{14}$ The latter value is ascribed to the $\nu_{\mathrm{CN}}$ band of free terminal $\mathrm{Fe}^{\mathrm{III}}{ }_{\mathrm{LS}}-\mathrm{CN}$ of the $\left[\mathrm{Fe}^{\mathrm{III}}(\mathrm{Tp})(\mathrm{CN})_{3}\right]^{-}$unit. $^{14}$ In addition, a significant change has also been observed in the $\nu_{\mathrm{BH}}$ absorption band of the coordinated $\mathrm{Tp}$ ligand. Upon an increase in the temperature, the intensity of the $\nu_{\mathrm{BH}}$ band decreases with the appearance of a new band at $2510 \mathrm{~cm}^{-1}$, which is similar to the value observed in (TBA) $\left[\mathrm{Fe}^{\mathrm{III}}(\mathrm{Tp})(\mathrm{CN})_{3}\right] \cdot \mathrm{H}_{2} \mathrm{O}$ (Figure $\mathrm{S} 7$ ). Interestingly, an important variation has also been noticed in the $\nu_{\mathrm{CO}}$ absorption band of the $\mathrm{L}$ ligand coordinated to cobalt centers. A decrease in the $\nu_{\mathrm{CO}}$ absorption band at $1667 \mathrm{~cm}^{-1}$ is observed with the formation of a new peak at $1646 \mathrm{~cm}^{-1}$, which lies in the range observed in the $\mathrm{HS}\left[\mathrm{Co}(\mathrm{L})_{3}\right]^{2+}$ complex $\left(1641 \mathrm{~cm}^{-1}\right.$; Figure S6). These changes in $\nu_{\mathrm{CN}}, \nu_{\mathrm{BH}}$, and $\nu_{\mathrm{CO}}$ are reversible upon cooling (Figures S10-S12). The overall results clearly suggest a reversible thermal conversion of the $\left\{\mathrm{Fe}_{\text {II }}^{\mathrm{II}}-\mathrm{CN}-\mathrm{Co}_{\mathrm{LS}}{ }_{\mathrm{LS}}\right\}$ pair to the $\left\{\mathrm{Fe}_{\mathrm{LS}}^{\mathrm{III}}-\mathrm{CN}-\mathrm{Co}_{\mathrm{HS}}^{\mathrm{II}}\right\}$ pair occurs in 1 via the intramolecular MMET process. ${ }^{12-20,22-25,37,39-41}$

$\mathrm{UV} /$ vis/near-IR spectroscopic studies were carried out on the building block (TBA) $\left[\mathrm{Fe}^{\mathrm{III}}(\mathrm{Tp})(\mathrm{CN})_{3}\right] \cdot \mathrm{H}_{2} \mathrm{O}$, $\left[\mathrm{Co}^{\mathrm{II}}(\mathrm{L})_{2}(\mathrm{NCMe})_{2}\right]^{2+}$, and complex $\mathbf{1}$ in both the solid and solution states at room temperature. The UV/vis spectra of $(\mathrm{TBA})\left[\mathrm{Fe}^{\mathrm{III}}(\mathrm{Tp})(\mathrm{CN})_{3}\right] \cdot \mathrm{H}_{2} \mathrm{O}$ in acetonitrile show a ligand-tometal charge-transfer (LMCT) transition band centered at around $408 \mathrm{~nm}$, while a LMCT band centered at around 330 $\mathrm{nm}$ was observed for $\left[\mathrm{Co}^{\mathrm{II}}(\mathrm{L})_{2}(\mathrm{NCMe})_{2}\right]^{2+}$ (Figure S13)..$^{15}$ For 1, the spectrum exhibits two sharp bands centered at around 337 and $420 \mathrm{~nm}$ with a broad band centered at around $695 \mathrm{~nm}$ (Figure S14). The former two bands are ascribed to the metal-to-ligand charge-transfer (MLCT) transition band coming from the $\left[\mathrm{Co}^{\mathrm{III}}(\mathrm{L})_{2}(\mathrm{NC})_{2}\right]^{3+}$ unit and the LMCT band coming from the $\left[\mathrm{Fe}^{\mathrm{II}}(\mathrm{Tp})(\mathrm{CN})_{3}\right]^{2-}$ unit, respectively, while the latter band is corresponding to a metal-to-metal chargetransfer (MMCT) transition band coming from the $\mathrm{Fe}^{\mathrm{II}}{ }_{\mathrm{LS}} \rightarrow$ $\mathrm{Co}_{\text {LS }}^{\mathrm{III}}$ unit (Figure S15). ${ }^{12-20,22-25,37,39-41}$ The UV/vis spectra of $\mathbf{1}$ in different solvents reveal an absorption spectrum similar to that in an acetonitrile solution (Figure S16). The solid-state spectrum of $\mathbf{1}$ displays an absorption band very similar to that of the solution-state spectrum (Figure S17), suggesting that the complex retained its identity in both the solid and solution states.

Electrochemical Studies. The electrochemical properties of $\mathbf{1}$, along with (TBA) $\left[\mathrm{Fe}^{\mathrm{III}}(\mathrm{Tp})(\mathrm{CN})_{3}\right] \cdot \mathrm{H}_{2} \mathrm{O}$ and [Co$\left.(\mathrm{L})_{2}(\mathrm{NCMe})_{2}\right]^{2+}$, were investigated by cyclic voltammetry $(\mathrm{CV})$, square-wave voltammetry, and differential-pulse voltammetry in an acetonitrile solution containing respective samples $(\sim 1 \mathrm{mM})$ with $0.1 \mathrm{M}(\mathrm{TBA}) \mathrm{PF}_{6}$ as an electrolyte at $300 \mathrm{~K}$ (Figures 2, S18, and S19 and Table S5). The cyclic

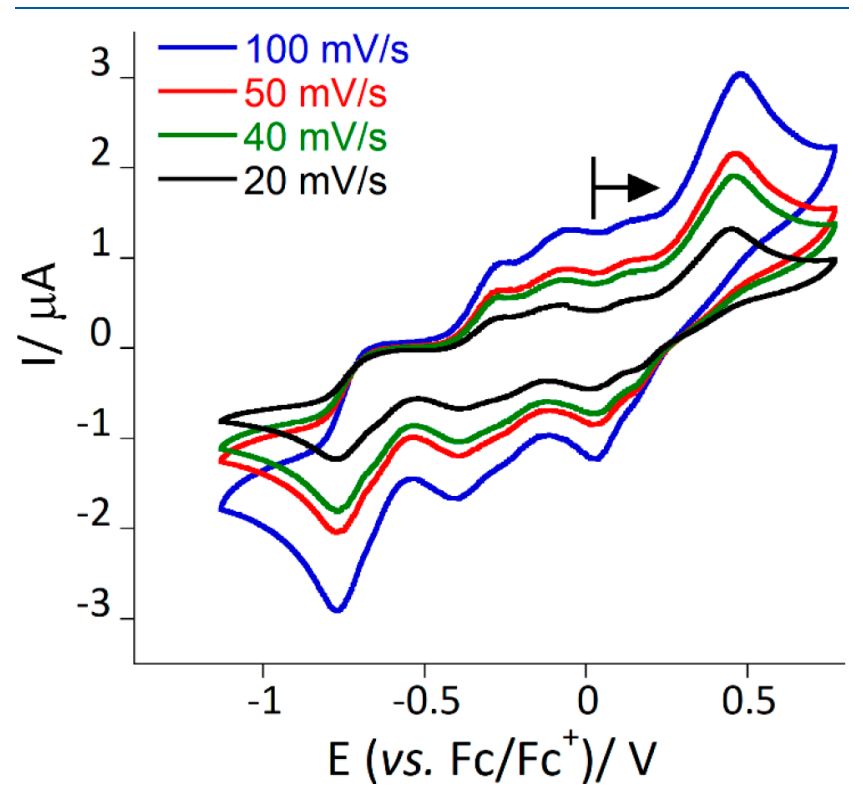

Figure 2. Cyclic voltammograms of $\mathbf{1}$ in acetonitrile containing $0.1 \mathrm{M}$ (TBA) $\mathrm{PF}_{6}$ as an electrolyte with various scan rates at $300 \mathrm{~K}$. Arrows indicate an open-circuit potential along with the direction of the potential sweep.

voltammogram of $(\mathrm{TBA})\left[\mathrm{Fe}^{\mathrm{III}}(\mathrm{Tp})(\mathrm{CN})_{3}\right] \cdot \mathrm{H}_{2} \mathrm{O}$ exhibits a quasi-reversible reduction for $\mathrm{Fe}^{\mathrm{III}}$ to $\mathrm{Fe}^{\mathrm{II}}$ at around $-0.81 \mathrm{~V}$ versus ferrocene/ferrocenium $\left(\mathrm{Fc} / \mathrm{Fc}^{+}\right)$, while a slow quasireversible oxidation process at around $0.22 \mathrm{~V}$ versus $\mathrm{Fc} / \mathrm{Fc}^{+}$ was observed for $\mathrm{Co}^{\mathrm{II}}$ to $\mathrm{Co}^{\mathrm{III}}$ in $\left[\mathrm{Co}(\mathrm{L})_{2}(\mathrm{NCMe})_{2}\right]^{2+}$ (Figure S18).

The cyclic voltammograms of 1 reveal a quasi-reversible oxidation process at around $0.08 \mathrm{~V}$ versus $\mathrm{Fc} / \mathrm{Fc}^{+}$, corresponding to oxidation of the iron(II) center $\left(\left\{\mathrm{Fe}_{2}{ }_{2} \mathrm{Co}_{2}{ }_{2}\right\}^{2+} /\right.$ $\left\{\mathrm{Fe}^{\mathrm{III}} \mathrm{Fe}^{\mathrm{II}} \mathrm{Co}_{2}{ }_{2}\right\}^{3+}$ along with an irreversible oxidation peak at around $0.47 \mathrm{~V}$ versus $\mathrm{Fc} / \mathrm{Fc}^{+}\left(E_{\mathrm{pc}}\right.$; Figure 2). ${ }^{12-20}$ The latter value is similar to that observed for $\left[\mathrm{Co}(\mathrm{L})_{2}(\mathrm{NCMe})_{2}\right]^{2+}$ (Figure S18, right). Apart from oxidation, the cyclic voltammograms also exhibit two quasi-reversible reductions for the cobalt(III) centers at around -0.15 and $-0.34 \mathrm{~V}$ versus $\mathrm{Fc} / \mathrm{Fc}^{+}\left(\left\{\mathrm{Fe}^{\mathrm{II}}{ }_{2} \mathrm{Co}^{\mathrm{III}}\right\}_{2}\right\}^{2+} /\left\{\mathrm{Fe}^{\mathrm{II}}{ }_{2} \mathrm{Co}^{\mathrm{III}} \mathrm{Co}^{\mathrm{II}}\right\}^{+}$and $\left.\left\{\mathrm{Fe}_{2}^{\mathrm{II}} \mathrm{Co}^{\mathrm{III}} \mathrm{Co}^{\mathrm{II}}\right\}^{+} /\left\{\mathrm{Fe}_{2}{ }_{2} \mathrm{Co}_{2}{ }_{2}\right\}\right)$. Also, the voltammograms show a quasi-reversible reduction process at around $-0.76 \mathrm{~V}$ versus $\mathrm{Fc} / \mathrm{Fc}^{+}$in $\mathbf{1}$, which is slightly lower than the value observed for the iron(III) building block, i.e., (TBA)$\left[\mathrm{Fe}^{\mathrm{III}}(\mathrm{Tp})(\mathrm{CN})_{3}\right] \cdot \mathrm{H}_{2} \mathrm{O}$ (Figure $\mathrm{S} 18$, left). These results are also consistent with the square-wave and differential-pulse voltammograms (Figure S19). The Gibbs free-energy difference $\left(\Delta G_{\mathrm{HL}}{ }^{0}\right)$ between the paramagnetic $\left\{\left(\mathrm{Fe}^{\mathrm{III}}\right)_{2}\left(\mathrm{Co}_{\mathrm{HS}}\right)_{2}\right\}$ 
and diamagnetic $\left\{\left(\mathrm{Fe}_{\mathrm{LS}}^{\mathrm{II}}\right)_{2}\left(\mathrm{Co}_{\mathrm{LS}}^{\mathrm{III}}\right)_{2}\right\}$ species correlates with the difference between the redox potentials of the iron and cobalt centers $\left(\Delta E=E_{\mathrm{Co}}{ }_{\text {III }} / \mathrm{Co}^{\text {II }}-E_{\mathrm{Fe}}{ }^{\text {II }} / \mathrm{Fe}^{\mathrm{III}}\right) .{ }^{12-20}$ The measured $|\Delta E|$ value for 1 is $0.23 \mathrm{~V}$ versus $\mathrm{Fc} / \mathrm{Fc}^{+}$, belonging in the range observed for similar $\left\{\mathrm{Fe}_{2} \mathrm{Co}_{2}\right\}$ square complexes. ${ }^{12-20}$ The corresponding $\Delta G_{\mathrm{HL}}{ }^{0}$ value of 1 suggests the possibilities of entropy-driven stimuli-responsive reversible electron transfer between the donor and acceptor in $\mathbf{1}$.

Differential Scanning Calorimetry (DSC). DSC studies were carried out for $\mathbf{1}$ to explore the possibilities of the thermoinduced MMET process, which typically follows a firstorder phase transition, and to estimate the associated changes in the thermodynamic parameters, i.e., enthalpy and entropy. $^{24,25}$ DSC measurements were performed in the temperature range of $300-420 \mathrm{~K}$, with different sweep rates varying from 15 to $5 \mathrm{~K} \mathrm{~min}^{-1}$ (Figure 3). DSC studies of 1

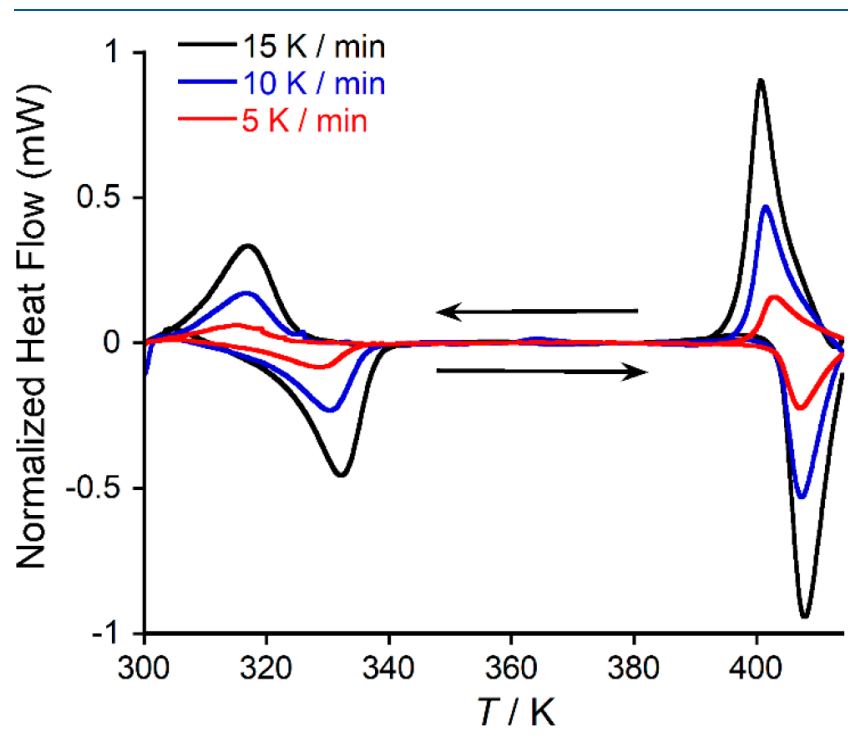

Figure 3. DSC plots of 1 shown between 300 and $420 \mathrm{~K}$ at different sweep rates.

show two reversible peaks at around 310-340 and 400-410 K, suggesting the first-order phase transition for 1. Upon heating/ cooling with a sweep rate of $10 \mathrm{~K} \mathrm{~min}^{-1}$, two sets of reversible endothermic/exothermic peaks were observed with a peak maximum at $332 / 316 \mathrm{~K}$ and $407 / 400 \mathrm{~K}$, respectively. These values suggest the presence of a two-step transition in 1 , which is consistent with the magnetic studies (vide infra). All of the thermodynamic parameters have been calculated, and the corresponding $\Delta H$ values were estimated to be $4.68(T \uparrow) / 5.06$ $(T \downarrow) \mathrm{kJ} \mathrm{mol}^{-1}$ and $8.78(T \uparrow) / 7.62(T \downarrow) \mathrm{kJ} \mathrm{mol}^{-1}$, respectively. The associated $\Delta S$ values were calculated to be $14.17(T \uparrow) /$ $15.98(T \downarrow)$ and $21.56(T \uparrow) / 19.01(T \downarrow) \mathrm{J} \mathrm{K}^{-1} \mathrm{~mol}^{-1}$, respectively. These $\Delta H$ and $\Delta S$ values match well with the obtained values for other MMET complexes having stepwise transitions. $^{24,25}$

Magnetic Studies. The temperature dependence of the magnetic susceptibility measurement was performed on polycrystalline samples of $\mathbf{1}$ in the temperature range of 2$420 \mathrm{~K}$ at a $1000 \mathrm{Oe}$ external magnetic field (Figure 4).

For 1, the measured $\chi T$ values $(\chi$ is the magnetic susceptibility equal to $M / H$ per $\left\{\mathrm{Fe}_{2} \mathrm{Co}_{2}\right\}$ unit) in the temperature range of $15-300 \mathrm{~K}$ are nearly constant with a value of $0.30 \mathrm{~cm}^{3} \mathrm{~mol}^{-1} \mathrm{~K}$, which is slightly higher than the value expected for two LS iron(II) ions $(S=0)$ and two LS

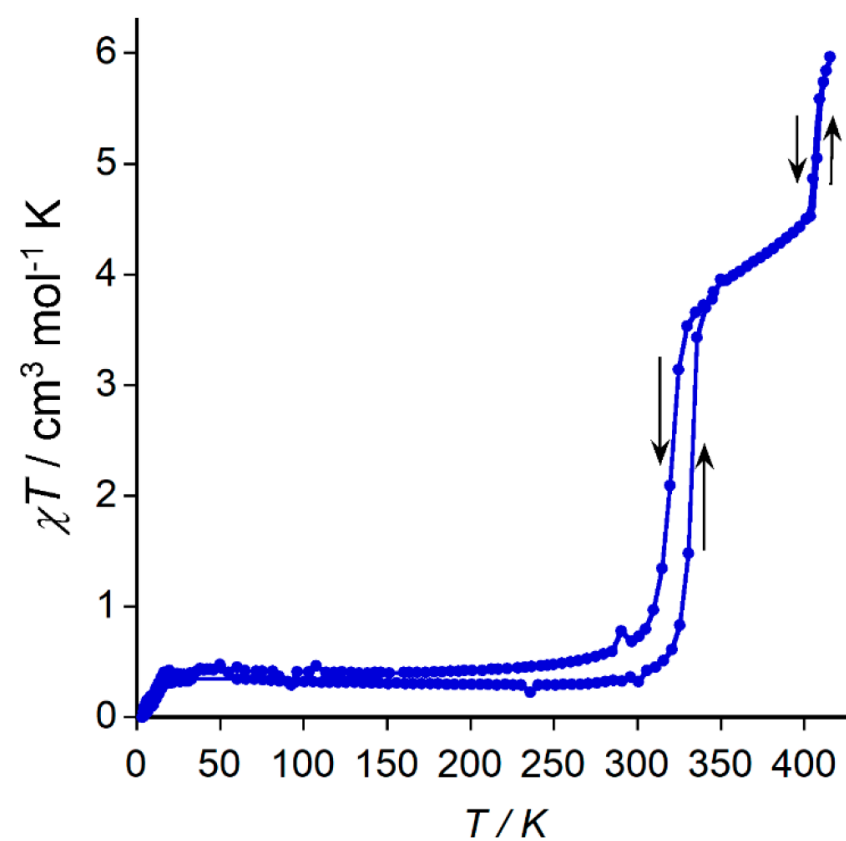

Figure 4. Temperature dependence of $\chi T$ for 1 under a 1000 Oe external magnetic field with a sweep rate of $2 \mathrm{~K} \mathrm{~min}^{-1}$.

cobalt(III) ions $(S=0)$. The slightly positive $\chi T$ value might be due to the presence of a small fraction of the residual paramagnetic $\left\{\mathrm{Fe}_{\mathrm{LS}}^{\mathrm{III}}\left(S={ }^{1} / 2\right)-\mathrm{Co}_{\mathrm{HS}}^{\mathrm{II}}(S=3 / 2)\right\}$ state. With increasing temperature, one interesting phenomenon has been observed starting from $310 \mathrm{~K}$. The $\chi T$ value increases abruptly with a transition temperature $T_{1 / 2}(1) \uparrow$ at $332 \mathrm{~K}$ to reach a plateau with values of $4.02-4.00 \mathrm{~cm}^{3} \mathrm{~mol}^{-1} \mathrm{~K}$ at 350 $\mathrm{K}$. This $\chi T$ value is higher than the value obtained for one LS iron(III) ion $\left(S={ }^{1} / 2 ; g \approx 2.6\right)^{14,16,17,42}$ and one HS cobalt(II) ion $(S=3 / 2 ; g \approx 2.4)^{14,16,17}$ both with significant orbital contributions, suggesting an intermediate phase with the $\left\{\mathrm{Fe}_{\mathrm{LS}}^{\mathrm{II}}(S=0)-\mathrm{Co}_{\mathrm{IS}}^{\mathrm{III}}(S=0)\right\}$ and $\left\{\mathrm{Fe}_{\mathrm{LS}}^{\mathrm{III}}\left(S={ }^{1} /{ }_{2}\right)-\right.$ $\left.\mathrm{Co}_{\mathrm{HS}}^{\mathrm{II}}(S=3 / 2)\right\}$ pairs in a ratio close to $1: 1$ generated via MMET between the iron and cobalt centers. ${ }^{14,16,17,24,25}$ Upon a further increase in the temperature, the $\chi T$ value increases sharply with a transition temperature $T_{1 / 2}(2) \uparrow=407 \mathrm{~K}$ to reach a value of $5.98 \mathrm{~cm}^{3} \mathrm{~mol}^{-1} \mathrm{~K}$ at $420 \mathrm{~K}$. This $\chi T$ value is slightly lower than the values observed for two LS iron(III) ions $(S=1 / 2 ; g \approx 2.6)$ and two HS cobalt(II) ions $(S=3 / 2 ; g$ $\approx 2.4$ ) with significant orbital contributions, which can be ascribed by the nonsaturation nature of the curve measured up to this temperaure. ${ }^{14,16,17,20,24,25}$

This indicates that the diamagnetic $\left\{\mathrm{Fe}^{\mathrm{II}}{ }_{\mathrm{LS}}(S=0)-\right.$ $\left.\mathrm{Co}_{\text {LS }}^{\text {III }}(S=0)\right\}_{2}$ ground state of $\mathbf{1}$ converts to the hightemperature paramagnetic $\left\{\mathrm{Fe}^{\mathrm{III}}{ }_{\mathrm{LS}}\left(S={ }^{1} /{ }_{2}\right)-\mathrm{Co}^{\mathrm{II}}{ }_{\mathrm{HS}}(S=3 / 2)\right\}_{2}$ state via a two-step MMET associated with spin transition on the cobalt center $\left(\mathrm{Co}^{\mathrm{III}}{ }_{\mathrm{LS}} \rightarrow \mathrm{Co}^{\mathrm{II}}{ }_{\mathrm{HS}}\right)$ upon an increase in the temperature. Because of the instability or possible decomposition of complex $\mathbf{1}$ at high temperature, these measurements do not show a plateau at $420 \mathrm{~K}$, but the transition is almost fully described. During the cooling mode with a sweep rate of $2 \mathrm{~K} \mathrm{~min}^{-1}$, a narrow thermal hysteresis of $2 \mathrm{~K}$ at $T_{1 / 2}(2) \downarrow=405 \mathrm{~K}$ and a wide thermal hysteresis of $12 \mathrm{~K}$ at $T_{1 / 2}(1) \downarrow=320 \mathrm{~K}$ have also been observed for 1 . The small decrease of the $\chi T$ values below $15 \mathrm{~K}$ is probably due to the combined effect coming from the intramolecular antiferromagnetic interactions or the anisotropy resulting from spin- 

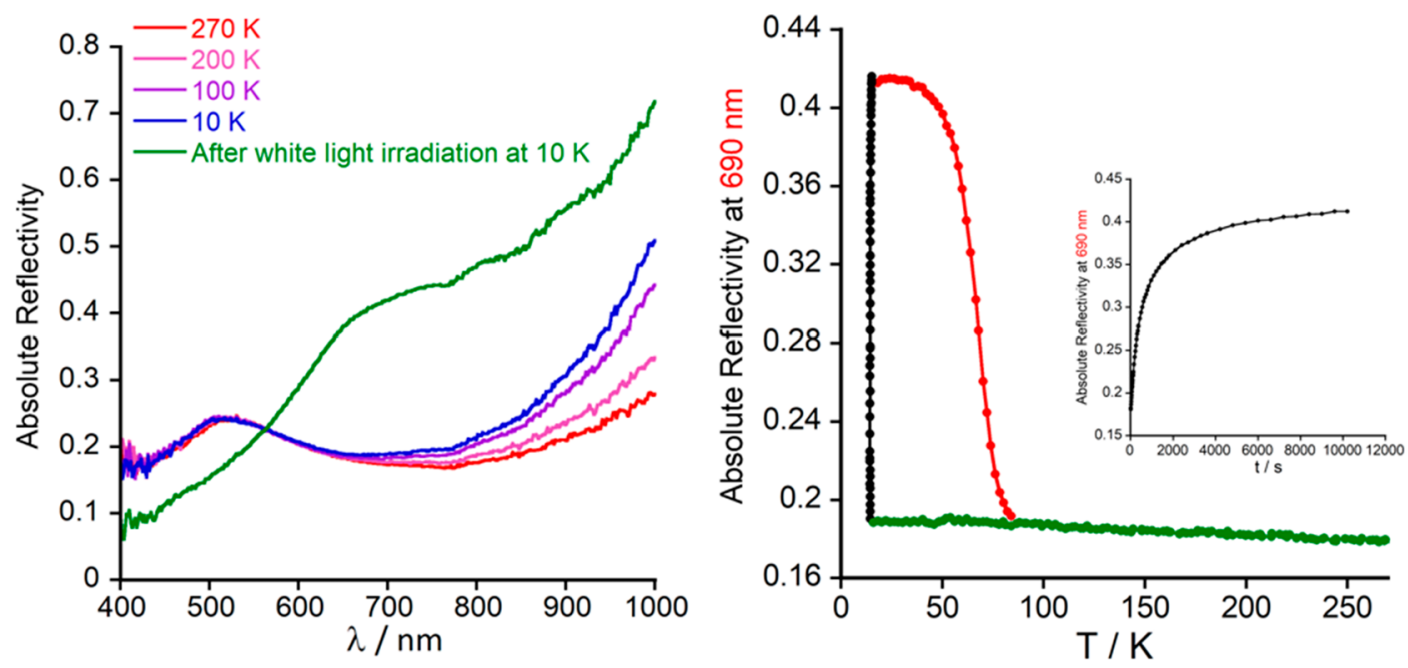

Figure 5. Left: Comparison of the surface reflectivity spectra in the temperature range of $270-10 \mathrm{~K}$ (red to blue) in the dark and after 160 min of white-light irradiation (green). Right: Thermal evolution of the absolute reflectivity signal plotted at $690 \mathrm{~nm}$ in cooling mode in the dark (270-10 $\mathrm{K}$, at $4 \mathrm{~K} \mathrm{~min}^{-1}$, green), during white-light irradiation $\left(0.6 \mathrm{~mW} \mathrm{~cm}^{-2}\right.$, at $10 \mathrm{~K}$, black), and in heating mode $\left(10-270 \mathrm{~K}\right.$, at $0.4 \mathrm{~K} \mathrm{~min}{ }^{-1}$, red) of 1 . Inset: Time evolution of the absolute reflectivity during white-light irradiation.

orbit coupling of HS cobalt(II) ions from the residual paramagnetic state.

The field-dependent magnetization studies were performed for 1 from 0 to $5 \mathrm{~T}$ at 2, 5, and $10 \mathrm{~K}$ (Figure S21, left). At $2 \mathrm{~K}$, the magnetization value is $0.60 \mu_{\mathrm{B}}$ for 1 at $5 \mathrm{~T}$, confirming the presence of $\left\{\mathrm{Fe}_{\mathrm{LS}}^{\mathrm{II}}(S=0)-\mathrm{Co}^{\mathrm{III}}{ }_{\mathrm{LS}}(S=0)\right\}$ pairs for $\mathbf{1}$, and the small magnetization value is coming from the residual paramagnetic $\left\{\mathrm{Fe}^{\mathrm{III}}{ }_{\mathrm{LS}}(S=1 / 2)-\mathrm{Co}^{\mathrm{II}}{ }_{\mathrm{HS}}\left(S={ }^{3} /{ }_{2}\right)\right\}$ state. $^{14,16,17,20,24,25,35}$ In addition, $M$ versus $H / T$ measurements exhibit nonsuperposition of the data on a single master curve (Figure S21, right). The nonsaturation and nonsuperposition of the magnetization curves for 1 suggest the presence of magnetic anisotropy due to the residual paramagnetic $\left\{\mathrm{Fe}^{\mathrm{III}}{ }_{\mathrm{LS}}(S=1 / 2)-\mathrm{Co}^{\mathrm{II}}{ }_{\mathrm{HS}}(S=3 / 2)\right\}$ state.

Optical Studies. Solid-state optical reflectivity measurements for complex 1 were carried out in the temperature range of $270-10 \mathrm{~K}$ with a sweep rate of $4 \mathrm{~K} \mathrm{~min}^{-1}$ in both cooling and heating modes. No significant changes were observed in the evolution of the absolute reflectivity as a function of the temperature. After, the sample was cooled in the dark to $10 \mathrm{~K}$, and the optical reflectivity of $\mathbf{1}$ was measured during irradiation with white light (power $0.6 \mathrm{~mW} \mathrm{~cm}^{-2}$ ) for $2 \mathrm{~h}$. For 1 , the spectrum resulting upon irradiation at $10 \mathrm{~K}$ shows a clear difference in the absolute reflectivity of ca. $500 \mathrm{~nm}$ and also in the range of $650-800 \mathrm{~nm}$ (Figure 5, left), the region expected for MMET between the iron and cobalt centers. This suggests the presence of a photoinduced MMET and the formation of the metastable paramagnetic $\left\{\mathrm{Fe}^{\mathrm{III}}{ }_{\mathrm{LS}}-\mathrm{CN}-\mathrm{Co}^{\mathrm{II}}{ }_{\mathrm{HS}}\right\}_{2}$ state of complex 1 at low temperature. ${ }^{14-20}$

The evolution of the absolute reflectivity at $690 \mathrm{~nm}$ versus time of irradiation indicates a rapid increase before it tends to saturation, and the major part of the photoexcitation was observed after $90 \mathrm{~min}$, reaching a value of 0.42 (from 0.18 ) after 160 min of light irradiation (Figure 5, right). After whitelight irradiation, the thermal stability of the photoinduced metastable state has also been studied in the dark by measuring the absolute reflectivity as a function of the temperature (sweep rate $0.4 \mathrm{~K} \mathrm{~min}^{-1}$ ). The reflectivity value was constant up to $60 \mathrm{~K}$, and then the value starts to decrease as the photoinduced metastable state thermally relaxed back to the diamagnetic ground state where complete relaxation was observed at $85 \mathrm{~K}$ ( $T_{\text {LIESST; }}$ Figure 5 , right), as further confirmed by photomagnetic measurements (vide infra). The absolute reflectivity data obtained beyond this temperature exhibited the same behavior as that in the dark. In addition to the above experiments, a set of 14 light-emitting diodes (LEDs; $385-1050 \mathrm{~nm}$ ) were also used to conduct the photoexcitation experiments at $10 \mathrm{~K}$ to find the most efficient irradiation wavelength for MMET (Figure S22). All of 14 LEDs show some photoeffect, i.e., an increase in the absolute reflectivity value, in agreement with the efficiency of the white light, where the maximum efficiency was observed for the $850 \mathrm{~nm}$ region (Figure S23, left). Consequently, $850 \mathrm{~nm}$ LED irradiation has been applied for photoexcitation at $10 \mathrm{~K}$. A more complete conversion to the photoinduced excited state can be reached from LED irradiation (for $1 \mathrm{~h}$ with $80 \mathrm{~mW} \mathrm{~cm}^{-2}$ ) than from white-light irradiation. After $850 \mathrm{~nm}$ LED light irradiation, the thermal stability of the photoinduced metastable state has also been studied in the dark by measuring the absolute reflectivity as a function of time (Figure S23, right). It is worth noting that the photoinduced metastable state has a long lifetime and was relatively stable at this temperature. Additionally, thermal relaxation of the photoinduced excited state to the ground state has been observed $\left(T_{\text {LIESST }}=90 \mathrm{~K}\right.$; sweep rate $0.4 \mathrm{~K}$ $\mathrm{min}^{-1}$ ), a little higher than that of white-light irradiation (Figure S24). Moreover, the effect of the LED power of 850 nm LED light was also studied (Figure S25), which indicates that $80 \mathrm{~mW} \mathrm{~cm} \mathrm{~cm}^{-2}$ brings the best ratio conversion by power. It is worth mentioning that the higher LED power does not significantly improve the conversion.

Photomagnetic Studies. ON Switching Mode. The photosensitivity of $\mathbf{1}$ was further investigated by measuring the magnetic properties under diode laser light irradiation at $20 \mathrm{~K}$ (measured $\chi T$ as a function of time) to explore the lightinduced MMET between iron and cobalt centers. Complex 1 was irradiated at $20 \mathrm{~K}$ and a 10000 Oe external magnetic dc field with four different diode laser sources $(405,532,635$, and $808 \mathrm{~nm}$ with powers ranging from 5 to $12 \mathrm{~mW} \mathrm{~cm}^{-2}$ ), covering the visible region. An obvious increase of the $\chi T$ value was observed for each laser source (photomagnetic effect); 
however, the maximum effect in the $\chi T$ value was obtained for $808 \mathrm{~nm}$ light (Figure 6), which is also consistent with the reflectivity and UV/vis studies (MMET from the $\mathrm{Fe}^{\mathrm{II}} \rightarrow$ Co ${ }_{\text {LS }}^{\text {III }}$ unit, vide supra).

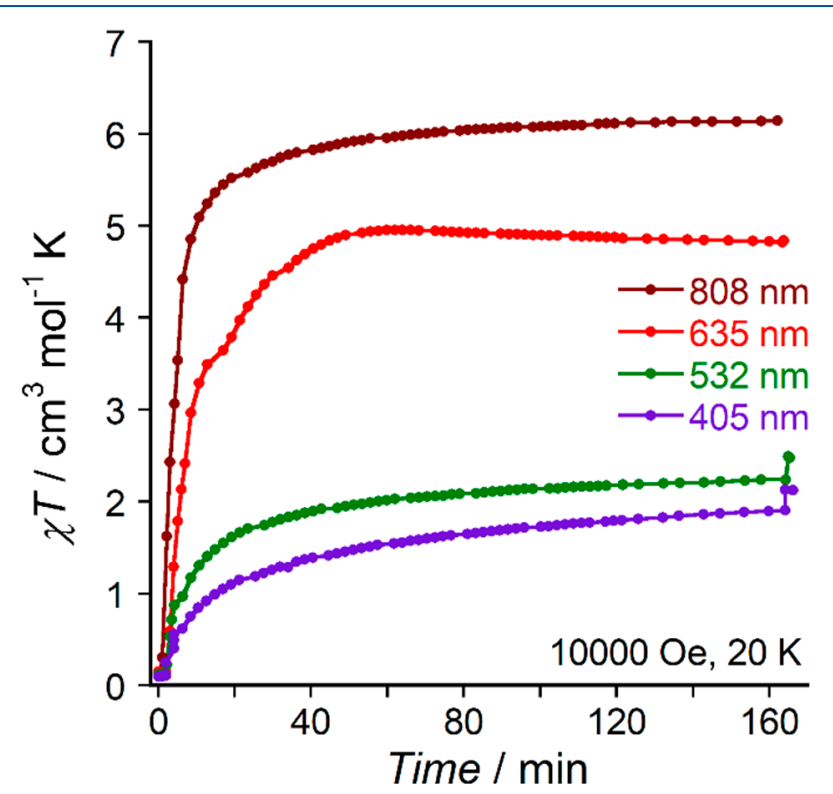

Figure 6. $\chi T$ versus time curves for 1 under 405, 532, 635, and 808 $\mathrm{nm}$ laser light irradiation at $20 \mathrm{~K}$ and 10000 Oe field.

Under $808 \mathrm{~nm}$ light irradiation, the $\chi T$ value increases rapidly to reach a saturation value of $6.14 \mathrm{~cm}^{3} \mathrm{~mol}^{-1} \mathrm{~K}$ after $170 \mathrm{~min}$. This value lies in the expected range observed in similar $\left\{\mathrm{Fe}_{2} \mathrm{Co}_{2}\right\}$ model complexes, ${ }^{14-20,24,25}$ signifying complete photoinduced conversion of the diamagnetic $\left\{\mathrm{Fe}^{\mathrm{II}}{ }_{\mathrm{LS}}-\right.$ $\left.\mathrm{CN}-\mathrm{Co}^{\mathrm{III}}{ }_{\mathrm{LS}}\right\}_{2}$ ground state to the metastable paramagnetic $\left\{\mathrm{Fe}^{\mathrm{III}}{ }_{\mathrm{LS}}-\mathrm{CN}-\mathrm{Co}_{\mathrm{HS}}^{\mathrm{II}}\right\}_{2}$ state at $20 \mathrm{~K}$. It is worth mentioning that around $25-70 \%$ a paramagnetic state can be achieved after irradiation with 405, 532, and $635 \mathrm{~nm}$ laser light. Fielddependent magnetization was studied for $\mathbf{1}$ after irradiation with all four wavelengths $(808,635,532$, and $405 \mathrm{~nm})$ from 0 to $5 \mathrm{~T}$ at $2 \mathrm{~K}$ (Figure S26). At $2 \mathrm{~K}$ and $5 \mathrm{~T}$, the magnetization value was $5.91 \mu_{\mathrm{B}}$ for 1 after irradiation with $808 \mathrm{~nm}$, confirming also the presence of the $\left\{\mathrm{Fe}_{\mathrm{LS}}^{\mathrm{III}}\left(S={ }^{1} / 2\right)-\right.$ $\left.\mathrm{Co}_{\mathrm{HS}}^{\mathrm{II}}(S=3 / 2)\right\}_{2}$ state at this temperature for $\mathbf{1}^{14-20,24,25}$ Moreover, all of these results are consistent with complete photoconversion of the diamagnetic $\left\{\mathrm{Fe}^{\mathrm{II}}{ }_{\mathrm{LS}}-\mathrm{CN}-\mathrm{Co}^{\mathrm{III}}{ }_{\mathrm{LS}}\right\}_{2}$ ground state to the metastable paramagnetic $\left\{\mathrm{Fe}^{\mathrm{III}}{ }_{\mathrm{LS}}-\mathrm{CN}-\right.$ $\left.\mathrm{Co}_{\mathrm{HS}}^{\mathrm{II}}\right\}_{2}$ state for $\mathbf{1}$.

To investigate the thermal stability and relaxation of the photoinduced metastable $\left\{\mathrm{Fe}^{\mathrm{III}}{ }_{\mathrm{LS}}-\mathrm{CN}-\mathrm{Co}_{\mathrm{HS}}^{\mathrm{II}}\right\}_{2}$ state, the temperature dependence of the $\chi T$ value was measured (sweep rate $0.4 \mathrm{~K} \mathrm{~min}^{-1}$ ) in the dark after it reached saturation (ca. $160 \mathrm{~min}$ at $808 \mathrm{~nm}$; Figure S27). In the dark, in the temperature range of $20-2 \mathrm{~K}$, the $\chi T$ value decreases sharply to reach a minimum from 6.20 to $4.60 \mathrm{~cm}^{3} \mathrm{~mol}^{-1} \mathrm{~K}$, indicating magnetic anisotropy coming from the cobalt(II) side and/or intermolecular antiferromagnetic interactions. ${ }^{14-20,24,25}$ Upon an increase in the temperature from 20 to $70 \mathrm{~K}, \chi T$ values remain almost constant, reaching a plateau value of 6.15 $\mathrm{cm}^{3} \mathrm{~mol}^{-1} \mathrm{~K}$, with such a small increase of the $\chi T$ value at low temperature suggesting intramolecular ferromagnetic interaction between the $\mathrm{Fe}^{\mathrm{III}}{ }_{\mathrm{LS}}$ and $\mathrm{Co}_{\mathrm{HS}}^{\mathrm{II}}$ centers in a photogenerated $\left.\left\{\mathrm{Fe}^{\mathrm{III}}{ }_{\mathrm{LS}}-\mathrm{CN}-\mathrm{Co}_{\mathrm{HS}}\right\}_{2}\right\}_{2}$ metastable state of $1 .^{14-20,24,25}$ Upon a further increase in the temperature, the photoinduced paramagnetic metastable state relaxes back to the thermodynamic diamagnetic $\left\{\mathrm{Fe}^{\mathrm{II}}{ }_{\mathrm{LS}}-\mathrm{CN}-\mathrm{Co}^{\mathrm{III}}{ }_{\mathrm{LS}}\right\}_{2}$ ground state at 91 $\mathrm{K}$, which is consistent with optical reflectivity studies (vide supra). Similar experiments have been carried out after irradiation with the other two laser lights e.g., 635 and 532 $\mathrm{nm}$ (sweep rate $0.4 \mathrm{~K} \mathrm{~min}^{-1}$ ). It is worth noting that relaxation of the photoinduced metastable state to the diamagnetic ground state happened nearly at the same temperature, $91 \mathrm{~K}$ (Figure 7).

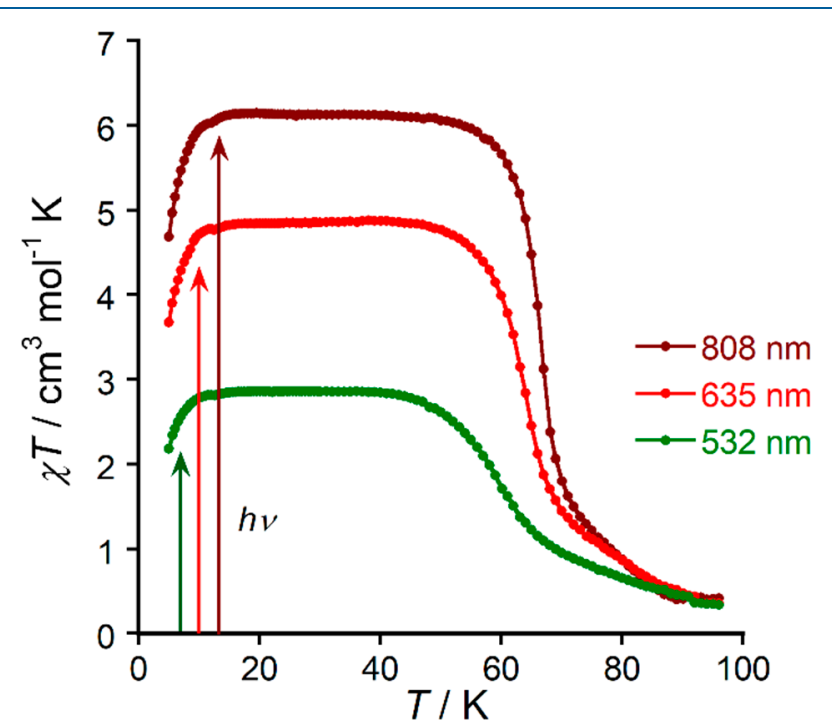

Figure 7. Temperature dependence of $\chi T$ of $\mathbf{1}$ after irradiation with 532,635 , and $808 \mathrm{~nm}$ laser light at 10000 Oe field (sweep rate $0.4 \mathrm{~K}$ $\left.\min ^{-1}\right)$.

OFF Switching Mode. Photomagnetic studies were further continued to explore the possibility of observing the reverse photoeffect, which converts the photoinduced metastable paramagnetic $\left\{\mathrm{Fe}_{\mathrm{LS}}^{\mathrm{III}}-\mathrm{CN}-\mathrm{Co}_{\mathrm{HS}}^{\mathrm{II}}\right\}_{2}$ state to the diamagnetic $\left\{\mathrm{Fe}_{\mathrm{LS}}^{\mathrm{II}}-\mathrm{CN}-\mathrm{Co}^{\mathrm{III}}{ }_{\mathrm{LS}}\right\}_{2}$ ground state via light-induced MMET at the same temperature compared to the thermal effect. After the saturation $\chi T$ values are reached using $808 \mathrm{~nm}$ laser light irradiation (ca. $160 \mathrm{~min}$ ), the evolution of $\chi T$ as a function of time was measured under three different laser sources (405, 532, and $635 \mathrm{~nm}$ ) at $20 \mathrm{~K}$ and 10000 Oe (Figure 8). Remarkably, all three wavelengths produced a significant reduction in the $\chi T$ values, suggesting depopulation of the photoinduced metastable paramagnetic $\left\{\mathrm{Fe}^{\mathrm{III}}{ }_{\mathrm{LS}}-\mathrm{CN}-\mathrm{Co}_{\mathrm{HS}}^{\mathrm{II}}\right\}_{2}$ state to the diamagnetic $\left\{\mathrm{Fe}_{\text {II }}^{\mathrm{II}}-\mathrm{CN}-\mathrm{Co}_{\mathrm{LS}}\right\}_{2}$ ground state. ${ }^{17}$ The maximum difference was observed upon irradiation with $532 \mathrm{~nm}$ laser light (matches well with the reflectivity and UV/ vis data; MMET from the $\mathrm{Co}_{\mathrm{HS}}^{\mathrm{II}} \rightarrow \mathrm{Fe}^{\mathrm{III}}{ }_{\mathrm{LS}}$ unit), where the $\chi T$ value decreases from 6.14 to $1.75 \mathrm{~cm}^{3} \mathrm{~mol}^{-1} \mathrm{~K}$ after $475 \mathrm{~min}$, indicating $75 \%$ recovery of the diamagnetic $\left\{\mathrm{Fe}^{\mathrm{II}}{ }_{\mathrm{LS}}-\mathrm{CN}-\right.$ $\left.\mathrm{Co}_{\text {LS }}^{\mathrm{III}}\right\}_{2}$ ground state at $20 \mathrm{~K}$.

The incomplete conversion is consistent with the results found during the above $\mathrm{ON}$ switching mode of photomagnetic measurements, where all laser sources show a significant increase of the $\chi T$ values (populating the paramagnetic $\left\{\mathrm{Fe}^{\mathrm{III}}{ }_{\mathrm{LS}}-\mathrm{CN}-\mathrm{Co}_{\mathrm{HS}}^{\mathrm{II}}\right\}_{2}$ state). Indeed, it is also observed that the most effective laser source in the ON switching mode is less effective in the OFF switching mode. In addition, for a particular wavelength, an increase and a decrease in the $\chi T$ values of photoinduced states show a significant difference in 


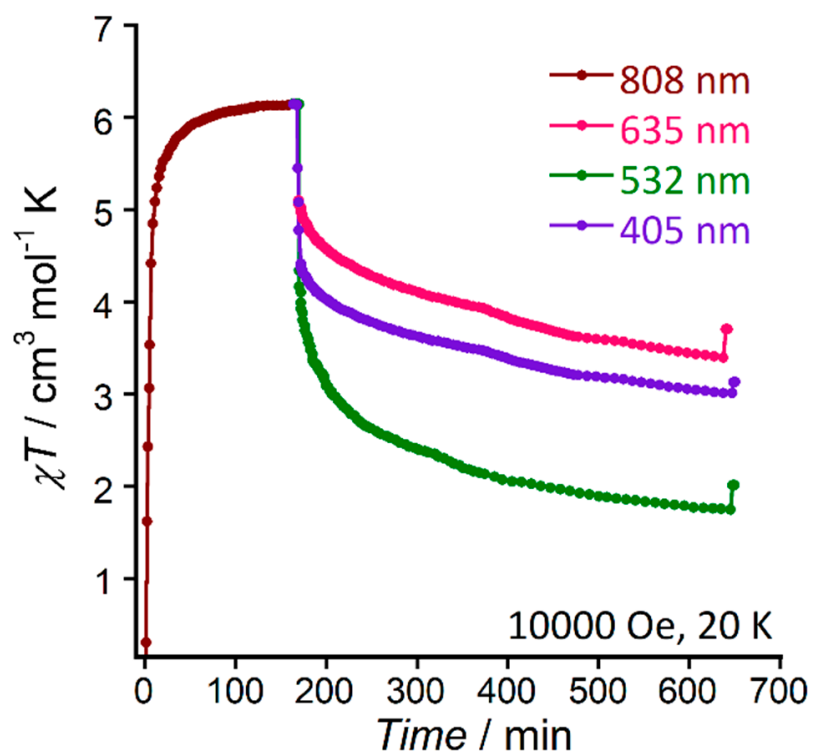

Figure 8. $\chi T$ versus time curves for 1 under $405,532,635$, and 808 $\mathrm{nm}$ laser light irradiation at $20 \mathrm{~K}$ and 10000 Oe field.

the ON and OFF switching modes, respectively. For example, in the case of the $405 \mathrm{~nm}$ laser, a ca. $28 \%$ conversion of the diamagnetic $\left\{\mathrm{Fe}^{\mathrm{II}}{ }_{\mathrm{LS}}-\mathrm{CN}-\mathrm{Co}^{\mathrm{III}}{ }_{\mathrm{LS}}\right\}_{2}$ state to the paramagnetic metastable $\left\{\mathrm{Fe}^{\mathrm{III}}{ }_{\mathrm{LS}}-\mathrm{CN}-\mathrm{Co}^{\mathrm{II}}{ }_{\mathrm{HS}}\right\}_{2}$ state in the ON switching mode has been observed, while a $51 \%$ reduction of the paramagnetic state to the diamagnetic ground state was observed in the OFF switching mode. This can be ascribed to a larger sample size, the thickness of the sample rather than a light penetration length, and faster kinetics in the $\mathrm{ON}$ switching mode in comparison to the OFF switching mode. ${ }^{17}$ It is worth noting that the photoconversion rate in the OFF switching mode is slower than that in the ON switching mode for complex 1, and a similar effect has been observed in another $\left[\mathrm{Fe}_{2} \mathrm{Co}_{2}\right]$ complex. ${ }^{17,25}$

ON/OFF Cycling. The photoreversibility studies were performed on 1 by measuring $\chi T$ versus time under several cycles of successive irradiation with $808 \mathrm{~nm}$ (most effective light for the $\mathrm{ON}$ mode) and $532 \mathrm{~nm}$ (most effective light for the OFF mode) lasers for ca. 200 and $1000 \mathrm{~min}$, respectively, at $20 \mathrm{~K}$ under $10000 \mathrm{Oe}$ field. Figure 9 represents variation of the $\chi T$ value with time after successive irradiation cycles. The individual curves do not superimpose each other; however, they are very similar. Besides, the first irradiation curve in the ON mode appears to be slightly different from the following ones. The $\chi T$ values obtained after successive irradiation at 808 $\mathrm{nm}$ are almost constant, while a gradual decrease in the $\chi T$ value has been noticed after successive $532 \mathrm{~nm}$ laser light irradiation cycles, which can be ascribed to an aging effect. After $808 \mathrm{~nm}$ light irradiation on the diamagnetic ground state, the $\chi T$ value increases from 0.12 to $6.14 \mathrm{~cm}^{3} \mathrm{~mol}^{-1} \mathrm{~K}$, whereas after $532 \mathrm{~nm}$ light irradiation on the photoexcited metastable state, the $\chi T$ value decreases from 6.14 to $1.76 \mathrm{~cm}^{3} \mathrm{~mol}^{-1} \mathrm{~K}$. These results suggest that a reversible ON/OFF switching of the diamagnetic $\left\{\mathrm{Fe}^{\mathrm{II}}{ }_{\mathrm{LS}}-\mathrm{CN}-\mathrm{Co}_{\mathrm{LS}}^{\mathrm{III}}\right\}_{2}$ and paramagnetic $\left\{\mathrm{Fe}^{\mathrm{III}}{ }_{\mathrm{LS}}-\mathrm{CN}-\mathrm{Co}_{\mathrm{HS}}^{\mathrm{II}}\right\}_{2}$ states of 1 can be achieved by 808 and $532 \mathrm{~nm}$ successive irradiation over numerous cycles at 20 $\mathrm{K}$. In addition, field-dependent magnetization was studied for $\mathbf{1}$ under cycles of successive irradiation at 808 and $532 \mathrm{~nm}$, from 0 to $5 \mathrm{~T}$ at $2 \mathrm{~K}$ (Figure S28). These results are consistent with the above findings.

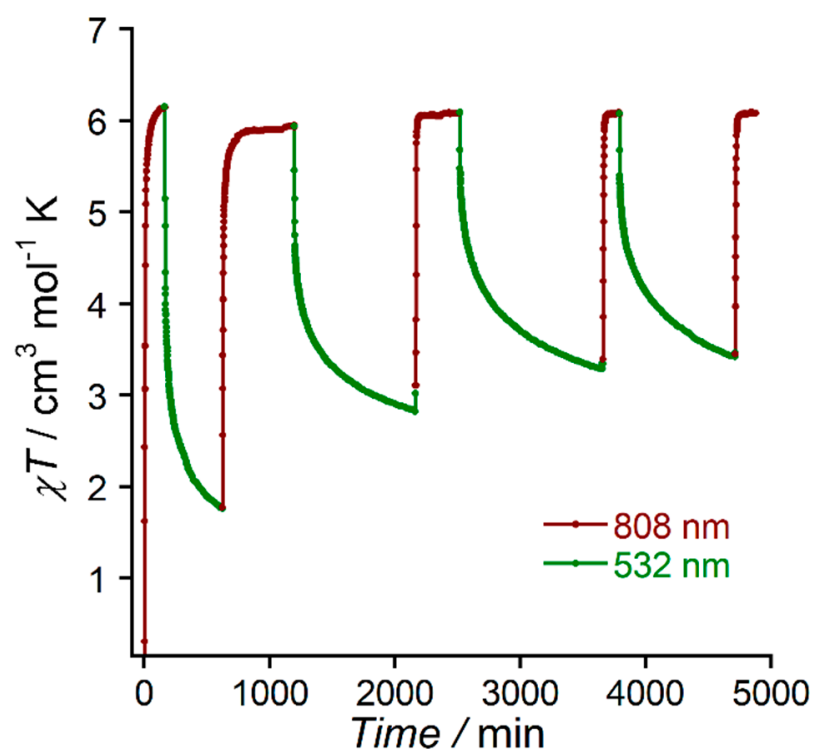

Figure 9. Plot of $\chi T$ versus time under cycles of successive irradiation with $808 \mathrm{~nm}\left(6 \mathrm{~mW} \mathrm{~cm}^{-2}\right)$ and $532 \mathrm{~nm}\left(10 \mathrm{~mW} \mathrm{~cm}^{-2}\right)$ at $20 \mathrm{~K}$ and 10000 Oe field of 1 .

Light-Induced Thermal Hysteresis Effect. Given the reversibility of thermal relaxation of the photoinduced metastable state and the possibility of observing the photoinduced memory effect, the photomagnetic measurement was further investigated following the temperature dependence of the $\chi T$ product under continuous $808 \mathrm{~nm}$ laser irradiation during both heating and cooling modes in the temperature range of $10-120 \mathrm{~K}$ (sweep rate $0.4 \mathrm{~K} \mathrm{~min}^{-1}$ ). Remarkably, an interesting hysteresis width of $27 \mathrm{~K}$ has been observed in 1, which is unique in MMET systems, termed the light-induced thermal hysteresis (LITH) effect $^{43}$ (Figure 10). First, the sample was irradiated with a $808 \mathrm{~nm}$ laser at $20 \mathrm{~K}$ for ca. 160 min under a 10000 Oe magnetic field to reach complete conversion of the diamagnetic $\left\{\mathrm{Fe}^{\mathrm{II}}{ }_{L S}-\mathrm{CN}-\mathrm{Co}^{\mathrm{III}}{ }_{\mathrm{LS}}\right\}_{2}$ state to the photomagnetic $\left\{\mathrm{Fe}^{\mathrm{III}}{ }_{\mathrm{LS}}-\mathrm{CN}-\mathrm{Co}_{\mathrm{HS}}\right\}_{2}$ metastable state, and the $808 \mathrm{~nm}$ light was continuously switched ON during the measurement process of thermal relaxation $(\chi T$ versus $T)$

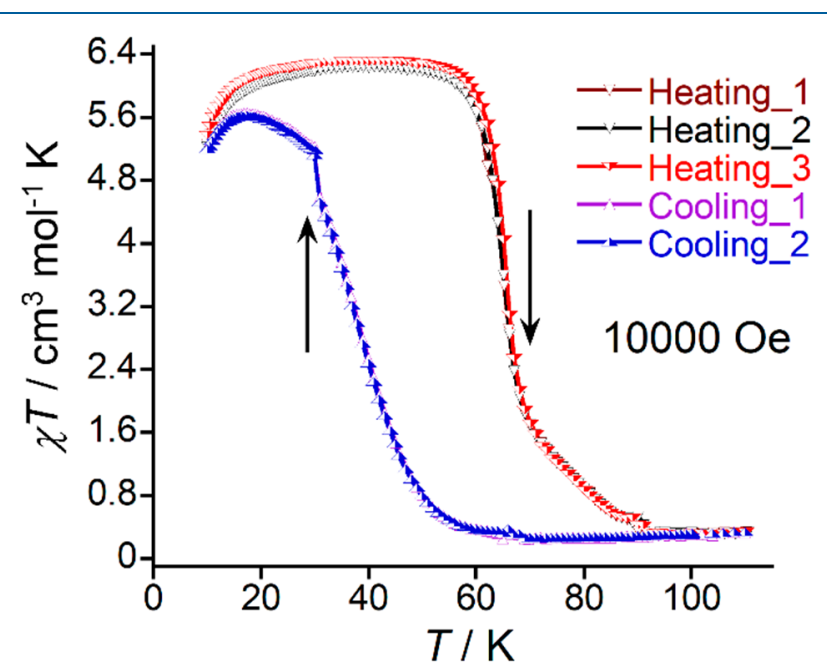

Figure 10. $\chi T$ versus $T$ curves of 1 under $808 \mathrm{~nm}$ light irradiation during cooling as well as warming with a sweep rate of $0.4 \mathrm{~K} \mathrm{~min}^{-1}$ at a 10000 Oe field. 
compared to the general thermal relaxation measurements (Figures 7 and S27).

Upon an increase in the temperature (sweep rate $0.4 \mathrm{~K}$ $\left.\min ^{-1}\right)$, the measured $\chi T$ value $\left(6.30 \mathrm{~cm}^{3} \mathrm{~mol}^{-1} \mathrm{~K}\right)$ at $20 \mathrm{~K}$ remained almost constant up to $60 \mathrm{~K}$ and then decreased smoothly to reach a value of $0.33 \mathrm{~cm}^{3} \mathrm{~mol}^{-1} \mathrm{~K}$ at $100 \mathrm{~K}$. In a successive cooling mode ( $808 \mathrm{~nm}$ light is switched $\mathrm{ON})$, the $\chi T$ value remained almost constant up to $70 \mathrm{~K}\left(0.27 \mathrm{~cm}^{3}\right.$ $\mathrm{mol}^{-1} \mathrm{~K}$ ) and then increased gradually to reach a plateau with $5.67 \mathrm{~cm}^{3} \mathrm{~mol}^{-1} \mathrm{~K}$ at $20-15 \mathrm{~K}$. Upon further cooling, $\chi T$ reached a value of $5.00 \mathrm{~cm}^{3} \mathrm{~mol}^{-1} \mathrm{~K}$ at $10 \mathrm{~K}$ (lower than the heating mode). The reversibility of the LITH effect was also confirmed by measuring $\chi T$ versus $T$ in numerous heating and cooling cycles while switching $\mathrm{ON}$ the $808 \mathrm{~nm}$ laser light (Figure 10). The temperature dependence of the $\chi T$ value (switching ON the $808 \mathrm{~nm}$ laser) exhibited an effect similar to that of the OFF switching mode (Figure S27) upon an increase of the temperature from 10 to $120 \mathrm{~K}$ (measuring thermal relaxation, $0.4 \mathrm{~K} \mathrm{~min}^{-1}$ ). When the sample was cooled to $10 \mathrm{~K}$ while switching $\mathrm{ON}$ the $808 \mathrm{~nm}$ laser $\left(0.4 \mathrm{~K} \mathrm{~min}^{-1}\right)$, the temperature dependence of the $\chi T$ value in both curves, i.e., cooling and heating modes (Figure 10, red and blue curves), followed different paths. It is worth noting that at $60 \mathrm{~K}$ the $\chi T$ value in the heating mode was $6.30 \mathrm{~cm}^{3} \mathrm{~mol}^{-1} \mathrm{~K}$, whereas in the cooling mode, the $\chi T$ value was $0.75 \mathrm{~cm}^{3} \mathrm{~mol}^{-1} \mathrm{~K}$ (switching ON the $808 \mathrm{~nm}$ laser), which indicates the LITH effect. While the temperature is being increased in the $\mathrm{ON}$ switching mode, a competition between photoexcitation of the diamagnetic state to the paramagnetic state and thermal relaxation of the photoinduced metastable paramagnetic state to the diamagnetic ground state is occurring. When the temperature is higher, the thermal relaxation process predominates over the photoexcitation effect, whereas at a lower temperature, the photoexcitation effect wins over thermal relaxation, responsible for this interesting LITH effect.

\section{CONCLUSION}

We have presented a new molecular model complex of [FeCo] PBAs, i.e., a $\left[\mathrm{Fe}_{2} \mathrm{Co}_{2}\right]$ square complex. X-ray structural analysis, (photo)magnetic, spectroscopic, and other physical measurements revealed that the redox potential of the building block, solvents, and capping ligand ( $\mathrm{Tp}$ ) played a major role in their physical properties. The $\left[\mathrm{Fe}_{2} \mathrm{Co}_{2}\right]$ complex exhibits reversible two-step thermo- and photoinduced MMET between the iron and cobalt centers, converting the diamagnetic phase $\left(\mathrm{Fe}^{\mathrm{II}}{ }_{\mathrm{LS}}-\right.$ $\left.\mathrm{CN}-\mathrm{Co}^{\mathrm{III}}{ }_{\mathrm{LS}}\right)$ to the paramagnetic phase $\left(\mathrm{Fe}^{\mathrm{III}}{ }_{\mathrm{LS}}-\mathrm{CN}-\mathrm{Co}_{\mathrm{HS}}^{\mathrm{II}}\right)$. Again, electrochemical studies suggested that the redox potential difference between the iron and cobalt units in the complex determines the electron-transfer probability. If the difference in the redox potential of the donor and acceptor units (iron and cobalt units) is too high or low, it will stabilize only one state (either the diamagnetic or paramagnetic state); when the redox potential difference is comparable with $k_{\mathrm{B}} T$ (order of magnitude of $\Delta G$ ), a reversible MMET is possible upon application of external perturbation, i.e., for complex $\mathbf{1}$. All interesting magnetic properties of the square complex can be explained by considering the different electronic states of the metal ions coming from the substituent group of capping ligands. 1 exhibits a reversible switching property, indicating that the energy gaps between the frontier orbitals of the iron and cobalt centers are close to each other, comparable with $k_{\mathrm{B}} T$. The magnetic (thermo- and photoinduced) bistability probably arises from MMET, which induces a reversible conversion between the diamagnetic phase $\left\{\mathrm{Fe}^{\mathrm{II}}{ }_{\mathrm{LS}}-\mathrm{CN}-\right.$ $\left.\mathrm{Co}^{\mathrm{III}}{ }_{\mathrm{LS}}\right\}_{2}$ and the paramagnetic phase $\left\{\mathrm{Fe}^{\mathrm{III}}{ }_{\mathrm{LS}}-\mathrm{CN}-\mathrm{Co}_{\mathrm{HS}}\right\}_{2}$. On the basis of the above data, diamagnetic-paramagnetic reversible switching of $\mathbf{1}$ is possible in two ways. So, the stimuli-responsive nature of $\mathbf{1}$ may pave a way in several new directions to rationally design materials with novel functionalities for applications as multiresponsive materials for future technological applications. Studies of the impact of substituents in the building block as well as in the capping ligand on MMET with detailed characterization of the photoinduced excited state using SCXRD and PXRD analyses are currently ongoing in our research group.

\section{EXPERIMENTAL SECTION}

Detailed experimental procedures, including materials, crystal structure analyses, physical methods, (photo)magnetic measurements, and optical studies, are described in the Supporting Information.

Synthesis of $\left\{\left[\mathrm{Fe}(\mathrm{Tp})(\mathrm{CN})_{3}\right]_{2}\left[\mathrm{Co}(\mathrm{L})_{2}\right]_{2}\right\}\left(\mathrm{BF}_{4}\right)_{2} \cdot 2 \mathrm{CH}_{3} \mathrm{CN} \cdot 6 \mathrm{H}_{2} \mathrm{O}$ (1). The reaction of $\mathrm{Co}\left(\mathrm{BF}_{4}\right)_{2} \cdot 6 \mathrm{H}_{2} \mathrm{O}(34 \mathrm{mg}, 0.1 \mathrm{mmol})$ and $\mathrm{L}(44$ $\mathrm{mg}, 0.2 \mathrm{mmol}$ ) in a mixture of solvent [acetonitrile and water mixture $(9: 1)](10 \mathrm{~mL})$ produces a brownish-pink solution. After $10 \mathrm{~min}$ of stirring, the resulting solution was added dropwise to a solution of $(\mathrm{TBA})\left[\mathrm{Fe}^{\mathrm{III}}(\mathrm{Tp})(\mathrm{CN})_{3}\right] \cdot \mathrm{H}_{2} \mathrm{O}(62.4 \mathrm{mg}, 0.1 \mathrm{mmol})$ in an acetonitrile and water mixture $(9: 1)(15 \mathrm{~mL})$. The resulting dark-green solution indicates MMET between the iron(III) and cobalt(II) centers. The reaction mixture was filtered and kept for crystallization by slow evaporation. After 10 days, dark-green rectangular plate-type crystals of 1 were obtained. Anal. Calcd for $\mathrm{C}_{72} \mathrm{H}_{94} \mathrm{Co}_{2} \mathrm{Fe}_{2} \mathrm{~N}_{36} \mathrm{O}_{10} \mathrm{~B}_{4} \mathrm{~F}_{8}$ (MW $\left.2048.63 \mathrm{~g} \mathrm{~mol}^{-1}\right)$ : C, 42.41; H, 4.63; N, 24.61. Found: C, 41.78; H, 4.90; N, 24.27. IR $\left(\mathrm{KBr}, \mathrm{cm}^{-1}\right): 3423,3154,3123,3106,2983,2940$, 2473, 2463, 2127, 2110, 2065, 1664, 1486, 1426, 1311, 1211, 1186, $1113,1086,1046,980,902,802,760,715,624,507,421$.

\section{AUTHOR INFORMATION}

\section{Corresponding Author}

Abhishake Mondal - Solid State and Structural Chemistry Unit, Indian Institute of Science, Bangalore 560012, India; ○ orcid.org/0000-0002-5061-2326; Email: mondal@ iisc.ac.in; http://m2ssscuiisc.in

\section{Authors}

Sujit Kamilya - Solid State and Structural Chemistry Unit, Indian Institute of Science, Bangalore 560012, India

Subrata Ghosh - Solid State and Structural Chemistry Unit, Indian Institute of Science, Bangalore 560012, India

Yanling Li - Institut Parisien de Chimie Moleculaire, Sorbonne Universite, CNRS, UMR 8232, Paris 750005, France 
Pierre Dechambenoit - Centre de Recherche Paul Pascal, Universite Bordeaux, CNRS, UMR 5031, Pessac 33600,

France; (1) orcid.org/0000-0001-7850-2260

Mathieu Rouzières - Centre de Recherche Paul Pascal, Universite Bordeaux, CNRS, UMR 5031, Pessac 33600, France

Rodrigue Lescouëzec - Institut Parisien de Chimie Moleculaire, Sorbonne Université, CNRS, UMR 8232, Paris 750005, France; 이이.0rid.0000-0003-3510-5112

Sakshi Mehta - Solid State and Structural Chemistry Unit, Indian Institute of Science, Bangalore 560012, India

\section{ACKNOWLEDGMENTS}

This research work is supported by the Indian Institute of Science (IISc), Bangalore, India [File No. R(VI)090/1076/ 2017-515], the Science \& Engineering Research Board (Project SRG/2019/000317), and the Department of Science and Technology (DST-RFBR; Indo-Russia Joint Research Funding, Project INT/RUS/RFBR/373). We are thankful to IISc and the Ministry of Human Resource Development (MHRD), Government of India, for funding the Start-up Research Grant (Grants SG/MHRD-17-0014 and SR/MHRD17-0011). S.K. thanks the Council of Scientific \& Industrial Research, Government of India, and S.G. and S.M. thank IISc for their fellowship.

\section{REFERENCES}

(1) Levchenko, G.; Bukin, G.; Fylymonov, H.; Li, Q.; Gaspar, A. B.; Real, J. A. Electrical Voltage Control of the Pressure-Induced Spin Transition at Room Temperature in the Microporous 3D Polymer $\left[\mathrm{Fe}(\mathrm{pz}) \mathrm{Pt}(\mathrm{CN})_{4}\right]$. J. Phys. Chem. C 2019, 123, 5642-5646.

(2) Mallah, T.; Thiébaut, S.; Verdaguer, M.; Veillet, P. High- $T_{c}$ Molecular-Based Magnets: Ferrimagnetic Mixed-Valence Chromium(III)-Chromium(II) Cyanides with $T_{\mathrm{c}}$ at 240 and $190 \mathrm{~K}$. Science 1993, 262, 1554-1557.

(3) Ksenofontov, V.; Levchenko, G.; Reiman, S.; Gutlich, P.; Bleuzen, A.; Escax, V.; Verdaguer, M. Pressure-induced electron transfer in ferrimagnetic Prussian blue analogs. Phys. Rev. B: Condens. Matter Mater. Phys. 2003, 68, 024415-024420.

(4) Bleuzen, A.; Lomenech, C.; Escax, V.; Villain, F.; Varret, F.; Cartier dit Moulin, C.; Verdaguer, M. Photoinduced Ferrimagnetic Systems in Prussian Blue Analogues $\mathrm{C}_{\mathrm{x}}^{\mathrm{I}} \mathrm{Co}_{4}\left[\mathrm{Fe}(\mathrm{CN})_{6}\right]_{\mathrm{y}}\left(\mathrm{C}^{\mathrm{I}}=\right.$ Alkali Cation). 1. Conditions to Observe the Phenomenon. J. Am. Chem. Soc. 2000, 122, 6648-6652.

(5) Sato, O.; Kawakami, T.; Kimura, M.; Hishiya, S.; Kubo, S.; Einaga, Y. Electric-Field-Induced Conductance Switching in $\mathrm{FeCo}$ Prussian Blue Analogues. J. Am. Chem. Soc. 2004, 126, 13176-13177.

(6) Kahn, O.; Martinez, C. J. Spin-Transition Polymers: From Molecular Materials Toward Memory Devices. Science 1998, 279, 4448.

(7) Miyamachi, T.; Gruber, M.; Davesne, V.; Bowen, M.; Boukari, S.; Joly, L.; Scheurer, F.; Rogez, G.; Yamada, T. K.; Ohresser, P.; Beaurepaire, E.; Wulfhekel, W. Robust spin crossover and memristance across a single molecule. Nat. Commun. 2012, 3, 938942.

(8) Urdampilleta, M.; Ayela, C.; Ducrot, P.-H.; Rosario-Amorin, D.; Mondal, A.; Rouzières, M.; Dechambenoit, P.; Mathonière, C.; Mathieu, F.; Dufour, I.; Clérac, R. Molecule-based microelectromechanical sensors. Sci. Rep. 2018, 8, 8016-8021.

(9) Sato, O.; Iyoda, T.; Fujishima, A.; Hashimoto, K. Photoinduced Magnetization of a Cobalt-Iron Cyanide. Science 1996, 272, 704-705.
(10) Berlinguette, C. P.; Dragulescu-Andrasi, A.; Sieber, A.; GalánMascarós, J. R.; Güdel, H.-U.; Achim, C.; Dunbar, K. R. A ChargeTransfer-Induced Spin Transition in the Discrete Cyanide-Bridged Complex $\left\{\left[\mathrm{Co}(\text { tmphen })_{2}\right]_{3}\left[\mathrm{Fe}(\mathrm{CN})_{6}\right]_{2}\right\}$. J. Am. Chem. Soc. 2004, 126, 6222-6223.

(11) Funck, K. E.; Prosvirin, A. V.; Mathoniere, C.; Clerac, R.; Dunbar, K. R. Light-induced excited spin state trapping and charge transfer in trigonal bipyramidal cyanide-bridged complexes. Inorg. Chem. 2011, 50, 2782-2789.

(12) Li, D.; Clérac, R.; Roubeau, O.; Harté, E.; Mathonière, C.; Le Bris, R.; Holmes, S. M. Magnetic and Optical Bistability Driven by Thermally and Photoinduced Intramolecular Electron Transfer in a Molecular Cobalt-Iron Prussian Blue Analogue. J. Am. Chem. Soc. 2008, 130, 252-258.

(13) Garnier, D.; Jiménez, J. R.; Li, Y.; von Bardeleben, J.; Journaux, Y.; Augenstein, T.; Moos, E. M. B.; Gamer, M. T.; Breher, F.; Lescouëzec, R. KC\{[Fe $\left.\left.{ }^{\mathrm{II}}(\mathrm{Tp})(\mathrm{CN})_{3}\right]_{4}\left[\mathrm{Co}^{\mathrm{III}}(\mathrm{pzTp})\right]_{3}\left[\mathrm{Co}^{\mathrm{II}}(\mathrm{pzTp})\right]\right\}$ : a neutral soluble model complex of photomagnetic Prussian blue analogues. Chem. Sci. 2016, 7, 4825-4831.

(14) Zhang, Y.; Li, D.; Clérac, R.; Kalisz, M.; Mathonière, C.; Holmes, S. M. Reversible Thermally and Photoinduced Electron Transfer in a Cyano-Bridged $\left\{\mathrm{Fe}_{2} \mathrm{Co}_{2}\right\}$ Square Complex. Angew. Chem., Int. Ed. 2010, 49, 3752-3756.

(15) Mercurol, J.; Li, Y.; Pardo, E.; Risset, O.; Seuleiman, M.; Rousselière, H.; Lescouëzec, R.; Julve, M. $\left[\mathrm{Fe}^{\mathrm{II}}{ }_{\mathrm{LS}} \mathrm{Co}^{\mathrm{III}}{ }_{\mathrm{LS}}\right]_{2} \Leftrightarrow$ $\left[\mathrm{Fe}^{\mathrm{III}}{ }_{\mathrm{LS}} \mathrm{Co}_{\mathrm{HS}}^{\mathrm{II}}\right]_{2}$ photoinduced conversion in a cyanide-bridged heterobimetallic molecular square. Chem. Commun. 2010, 46, 8995-8997.

(16) Nihei, M.; Sekine, Y.; Suganami, N.; Nakazawa, K.; Nakao, A.; Nakao, H.; Murakami, Y.; Oshio, H. Controlled Intramolecular Electron Transfers in Cyanide-Bridged Molecular Squares by Chemical Modifications and External Stimuli. J. Am. Chem. Soc. 2011, 133, 3592-3600.

(17) Mondal, A.; Li, Y.; Seuleiman, M.; Julve, M.; Toupet, L.; BuronLe Cointe, M.; Lescouëzec, R. On/Off Photoswitching in a CyanideBridged $\left\{\mathrm{Fe}_{2} \mathrm{Co}_{2}\right\}$ Magnetic Molecular Square. J. Am. Chem. Soc. 2013, 135, 1653-1656.

(18) Zhang, Y.-Z.; Ferko, P.; Siretanu, D.; Ababei, R.; Rath, N. P.; Shaw, M. J.; Clérac, R.; Mathonière, C.; Holmes, S. M. Thermochromic and Photoresponsive Cyanometalate Fe/Co Squares: Toward Control of the Electron Transfer Temperature. J. Am. Chem. Soc. 2014, 136, 16854-16864.

(19) De, S.; Jiménez, J.-R.; Li, Y.; Chamoreau, L.-M.; Flambard, A.; Journaux, Y.; Bousseksou, A.; Lescouëzec, R. One synthesis: two redox states. Temperature-oriented crystallization of a charge transfer $\left\{\mathrm{Fe}_{2} \mathrm{Co}_{2}\right\}$ square complex in a $\left\{\mathrm{Fe}^{\mathrm{II}}{ }_{\mathrm{LS}} \mathrm{Co}^{\mathrm{III}}{ }_{\mathrm{LS}}\right\}_{2}$ diamagnetic or $\left\{\mathrm{Fe}^{\mathrm{III}}{ }_{\mathrm{LS}} \mathrm{Co}^{\mathrm{II}}{ }_{\mathrm{HS}}\right\}_{2}$ paramagnetic state. RSC Adv. 2016, 6, 17456-17459.

(20) Nihei, M.; Yanai, Y.; Hsu, I. J.; Sekine, Y.; Oshio, H. A Hydrogen-Bonded Cyanide-Bridged $\left[\mathrm{Co}_{2} \mathrm{Fe}_{2}\right]$ Square Complex Exhibiting a Three-Step Spin Transition. Angew. Chem., Int. Ed. 2017, 56, 591-594.

(21) Lescouezec, R.; Li, Y.; Benchohra, A.; Xu, B.; Baptiste, B.; Béneut, K.; Parisiades, P.; Delbes, L.; Soyer, A.; Boukheddaden, K. Pressure-Induced Conversion of a Paramagnetic FeCo Complex into a Molecular Magnetic Switch with Tuneable Hysteresis. Angew. Chem., Int. Ed. 2020, DOI: 10.1002/anie.202008051.

(22) Jeon, I.-R.; Calancea, S.; Panja, A.; Piñero Cruz, D. M.; Koumousi, E. S.; Dechambenoit, P.; Coulon, C.; Wattiaux, A.; Rosa, P.; Mathonière, C.; Clérac, R. Spin crossover or intra-molecular electron transfer in a cyanido-bridged $\mathrm{Fe} / \mathrm{Co}$ dinuclear dumbbell: a matter of state. Chem. Sci. 2013, 4, 2463-2470.

(23) Koumousi, E. S.; Jeon, I.-R.; Gao, Q.; Dechambenoit, P.; Woodruff, D. N.; Merzeau, P.; Buisson, L.; Jia, X.; Li, D.; Volatron, F.; Mathonière, C.; Clérac, R. Metal-to-Metal Electron Transfer in $\mathrm{Co} / \mathrm{Fe}$ Prussian Blue Molecular Analogues: The Ultimate Miniaturization. J. Am. Chem. Soc. 2014, 136, 15461-15464.

(24) Aguilà, D.; Prado, Y.; Koumousi, E. S.; Mathonière, C.; Clérac, R. Switchable $\mathrm{Fe} / \mathrm{Co}$ Prussian blue networks and molecular analogues. Chem. Soc. Rev. 2016, 45, 203-224. 
(25) Mathonière, C. Metal-to-Metal Electron Transfer: A Powerful Tool for the Design of Switchable Coordination Compounds. Eur. J. Inorg. Chem. 2018, 2018, 248-258.

(26) Li, J.; Wu, S.; Su, S.; Kanegawa, S.; Sato, O. Manipulating Slow Magnetic Relaxation by Light in a Charge Transfer $\left\{\mathrm{Fe}_{2} \mathrm{Co}\right\}$ Complex. Chem. - Eur. J. 2020, 26, 3259-3263.

(27) Nihei, M.; Okamoto, Y.; Sekine, Y.; Hoshino, N.; Shiga, T.; Liu, I. P.-C.; Oshio, H. A Light-Induced Phase Exhibiting Slow Magnetic Relaxation in a Cyanide-Bridged $\left[\mathrm{Fe}_{4} \mathrm{Co}_{2}\right]$ Complex. Angew. Chem., Int. Ed. 2012, 51, 6361-6364.

(28) Hoshino, N.; Iijima, F.; Newton, G. N.; Yoshida, N.; Shiga, T.; Nojiri, H.; Nakao, A.; Kumai, R.; Murakami, Y.; Oshio, H. Three-way switching in a cyanide-bridged [CoFe] chain. Nat. Chem. 2012, 4, 921-926.

(29) Dong, D.-P.; Liu, T.; Kanegawa, S.; Kang, S.; Sato, O.; He, C.; Duan, C.-Y. Photoswitchable Dynamic Magnetic Relaxation in a WellIsolated $\left\{\mathrm{Fe}_{2} \mathrm{Co}\right\}$ Double-Zigzag Chain. Angew. Chem., Int. Ed. 2012, $51,5119-5123$.

(30) Baker, M. L.; Kitagawa, Y.; Nakamura, T.; Tazoe, K.; Narumi, Y.; Kotani, Y.; Iijima, F.; Newton, G. N.; Okumura, M.; Oshio, H.; Nojiri, H. X-ray magnetic circular dichroism investigation of the electron transfer phenomena responsible for magnetic switching in a cyanide-bridged [CoFe] chain. Inorg. Chem. 2013, 52, 13956-13962. (31) Jiang, W.; Jiao, C.; Meng, Y.; Zhao, L.; Liu, Q.; Liu, T. Switching single chain magnet behavior via photoinduced bidirectional metal-to-metal charge transfer. Chem. Sci. 2018, 9, 617-622.

(32) Bordage, A.; Moulin, R.; Fonda, E.; Fornasieri, G.; Rivière, E.; Bleuzen, A. Evidence of the Core-Shell Structure of (Photo)magnetic CoFe Prussian Blue Analogue Nanoparticles and Peculiar Behavior of the Surface Species. J. Am. Chem. Soc. 2018, 140, 10332-10343.

(33) Pinsky, M.; Avnir, D. Continuous Symmetry Measures. 5. The Classical Polyhedra. Inorg. Chem. 1998, 37, 5575-5582.

(34) Spek, A. PLATON SQUEEZE: a tool for the calculation of the disordered solvent contribution to the calculated structure factors. Acta Crystallogr., Sect. C: Struct. Chem. 2015, 71, 9-18.

(35) Jiménez, J. R.; Mondal, A.; Chamoreau, L. M.; Fertey, P.; Tuna, F.; Julve, M.; Bousseksou, A.; Lescouëzec, R.; Lisnard, L. An $\left\{\mathrm{Fe}_{60}\right\}$ tetrahedral cage: building nanoscopic molecular assemblies through cyanometallate and alkoxo linkers. Dalton Trans. 2016, 45, 1761017615.

(36) Mondal, A.; Durdevic, S.; Chamoreau, L.-M.; Journaux, Y.; Julve, M.; Lisnard, L.; Lescouëzec, R. A cyanide and hydroxo-bridged nanocage: a new generation of coordination clusters. Chem. Commun. 2013, 49, 1181-1183.

(37) Pardo, E.; Verdaguer, M.; Herson, P.; Rousseliere, H.; Cano, J.; Julve, M.; Lloret, F.; Lescouezec, R. Synthesis, crystal structures, and magnetic properties of a new family of heterometallic cyanide-bridged $\mathrm{Fe}^{\mathrm{III}}{ }_{2} \mathrm{M}^{\mathrm{II}}{ }_{2}(\mathrm{M}=\mathrm{Mn}, \mathrm{Ni}$, and $\mathrm{Co})$ square complexes. Inorg. Chem. 2011, 50, 6250-6262.

(38) Ghosh, S.; Selvamani, S.; Mehta, S.; Mondal, A. Reversible Thermo-Induced Spin Crossover in a Mononuclear cis-DicyanamidoCobalt(II) Complex Containing Macrocyclic Tetradentate Ligand. Dalton Trans. 2020, 49, 9208.

(39) Mondal, A.; Li, Y.; Herson, P.; Seuleiman, M.; Boillot, M.-L.; Rivière, E.; Julve, M.; Rechignat, L.; Bousseksou, A.; Lescouëzec, R. Photomagnetic effect in a cyanide-bridged mixed-valence $\left\{\mathrm{Fe}_{2}^{\mathrm{II}} \mathrm{Fe}_{2}{ }_{2}\right\}$ molecular square. Chem. Commun. 2012, 48, 5653-5655.

(40) Mondal, A.; Chamoreau, L.-M.; Li, Y.; Journaux, Y.; Seuleiman, M.; Lescouëzec, R. W-Co Discrete Complex Exhibiting Photo- and Thermo-Induced Magnetisation. Chem. - Eur. J. 2013, 19, 76827685.

(41) Bleuzen, A.; Marvaud, V.; Mathoniere, C.; Sieklucka, B.; Verdaguer, M. Photomagnetism in clusters and extended moleculebased magnets. Inorg. Chem. 2009, 48, 3453-3466.

(42) Ridier, K.; Mondal, A.; Boilleau, C.; Cador, O.; Gillon, B.; Chaboussant, G.; Le Guennic, B.; Costuas, K.; Lescouëzec, R. Polarized Neutron Diffraction to Probe Local Magnetic Anisotropy of a Low-Spin Fe(III) Complex. Angew. Chem., Int. Ed. 2016, 55, 39633967.
(43) Letard, J. F.; Guionneau, P.; Rabardel, L.; Howard, J. A.; Goeta, A. E.; Chasseau, D.; Kahn, O. Structural, Magnetic, and Photomagnetic Studies of a Mononuclear Iron(II) Derivative Exhibiting an Exceptionally Abrupt Spin Transition. Light-Induced Thermal Hysteresis Phenomenon. Inorg. Chem. 1998, 37, 4432-4441. 